\title{
5. THE OLIGOCENE TIME SCALE AND CYCLOSTRATIGRAPHY ON THE CEARA RISE, WESTERN EQUATORIAL ATLANTIC ${ }^{1}$
}

\author{
G.P. Weedon, ${ }^{2}$ N.J. Shackleton, ${ }^{3}$ and P.N. Pearson ${ }^{4}$
}

\begin{abstract}
On the Ceara Rise, complete Oligocene sections were recovered at Sites 925 and 929, and part of the Oligocene was recovered at Sites 926 and 928 during Ocean Drilling Program Leg 154. At all the sites, high-resolution shipboard measurements of magnetic susceptibility (MS) and light reflectance record persistent decimeter- to meter-scale cyclicity in the pelagic sediments. The cyclicity primarily relates to variations in the calcium carbonate contents. Spectral analysis shows that the cycles are regular in thickness, implying a regular fluctuation in the environment of deposition. Dating, constrained by the current chronometric scale and biostratigraphic datum levels, indicates that this cyclicity records the 40,000-yr obliquity orbital-climatic signal.

High-resolution lithostratigraphic correlation between sites is difficult because of the independent variations in sedimentation rate at each site, combined with the occurrence of slumps and carbonate turbidites, as well as a fault at Site 925 . The spectral results were used to constrain the wavelength of the 40,000-yr cyclicity and hence infer pelagic sedimentation rates. For each site the reflectance data, omitting the results from the redeposited sediment, were replotted in cumulative time relative to the end of the Oligocene. Correlation of the data between sites, once plotted on the independent cumulative time scales, allowed the development of a "composite" interval time scale for the Ceara Rise sediments. This spans the mid- to latest Oligocene (i.e., planktonic foraminiferal Biozones P20-P22 and nannofossil Biozones CP18-CP19b). The duration of the earliest Oligocene was estimated using data from Site 925 only. The time scale for the mid- to late Oligocene, which spans approximately 6 m.y., permits detailed correlation of other parameters such as isotopic data between sites on the Ceara Rise. The new biozone duration estimates and the temporal relationships between the planktonic foraminifer and nannofossil biozones differ substantially from published time scales.
\end{abstract}

\section{INTRODUCTION}

Following Pleistocene studies based on oxygen isotope time series (Hays et al., 1976; Imbrie et al., 1984), it is now widely accepted that orbitally driven variations in insolation have caused quasi-periodic climatic oscillations. Over the last 15 years, many studies have shown the prevalence of orbital-climatic forcing in deep-sea sedimentary strata from throughout the Phanerozoic (Fischer et al., 1990). However, it is frequently difficult to relate pre-Pliocene regular sedimentary cyclicity to a specific controlling factor such as productivity. Consequently, it has been suggested that a more immediately fruitful endeavor for ancient strata would be to exploit the stratigraphic potential of high-resolution compositional time series (Weedon, 1993). The development of a standard globally applicable benthic oxygen isotope stratigraphy was initially used to refine dating in the Pliocene to Holocene by "tuning" isolated regular oxygen isotopic oscillations either to a model of ice volume changes driven by the inferred insolation history or to the insolation history itself (e.g., Hays et al., 1976; Shackleton et al., 1990). Recently, a more general approach using time series of parameters, such as bedding patterns, percent $\mathrm{CaCO}_{3}$, magnetic susceptibility, and so on, has been used to improve dating at the expense of providing a global stratigraphic standard time series (Hilgen and Langereis, 1989; Hilgen, 1991; Shackleton et al., 1995).

This study concerns the use of reflectance and magnetic susceptibility measurements from pelagic Oligocene sediments drilled on the

${ }^{1}$ Shackleton, N.J., Curry, W.B., Richter, C., and Bralower, T.J. (Eds.), 1997. Proc. ODP, Sci. Results, 154: College Station, TX (Ocean Drilling Program).

${ }^{2}$ Department of Geology, University of Luton, Park Square, Luton, Bedfordshire LU1 3JU, United Kingdom. graham.weedon@luton.ac.uk

${ }^{3}$ Godwin Laboratory, University of Cambridge, Free School Lane, Cambridge, Cambridgeshire, United Kingdom.

${ }^{4}$ Department of Geology, Wills Memorial Building, University of Bristol, Queen's Road, Bristol BS8 1RJ, United Kingdom.
Ceara Rise during Ocean Drilling Program (ODP) Leg 154. The time series are examined in the depth domain for evidence of the regular sedimentary cyclicity, which is diagnostic of orbital-climatic forcing (Weedon, 1993). These strata are particularly well suited for this because there are high net sedimentation rates and they are free of cherts, which frequently affect coring recovery in deep-sea Oligocene sections. The records have been used to produce a cyclostratigraphy that allows estimation of the duration of the whole Oligocene and the associated planktonic foraminifer and nannofossil biozones. This work resembles previous studies of Mesozoic cyclic sediments in that a tuning target in the form of an insolation history was not used, and no absolute ages can be assigned to particular horizons. Instead, estimates of interval durations are derived and compared with estimates provided by the standard chronostratigraphic dates in the literature. Earlier work, using what could be termed an "interval dating" method (as opposed to relative or absolute dating), mainly concentrated on the Cretaceous and Devonian (e.g., Gale, 1989; Herbert, 1992; Sprenger and Ten Kate, 1993; House, 1995). In addition, it has been shown that orbital eccentricity and obliquity cycles are recorded by variations in grain size in continental shelf sediments in the original type section of the lower Oligocene in Belgium (Van Echelpoel and Weedon, 1990). Mead et al. (1986) and Hartl et al. (1995) have also used magnetic susceptibility time series to study Milankovitch cyclicity in Oligocene deep-sea sediments from the South Atlantic.

\section{TIME SERIES FROM CYCLIC PELAGIC SEDIMENTS}

The Oligocene was penetrated completely at Sites 925 and 929 and partially at Sites 926 and 928 (Curry, Shackleton, Richter, et al., 1995). The various sites provide a $1.5-\mathrm{km}$ depth transect within a relatively small area (Fig. 1). Only single holes were drilled in the Oligocene section at each site, thus preventing development of a ship- 


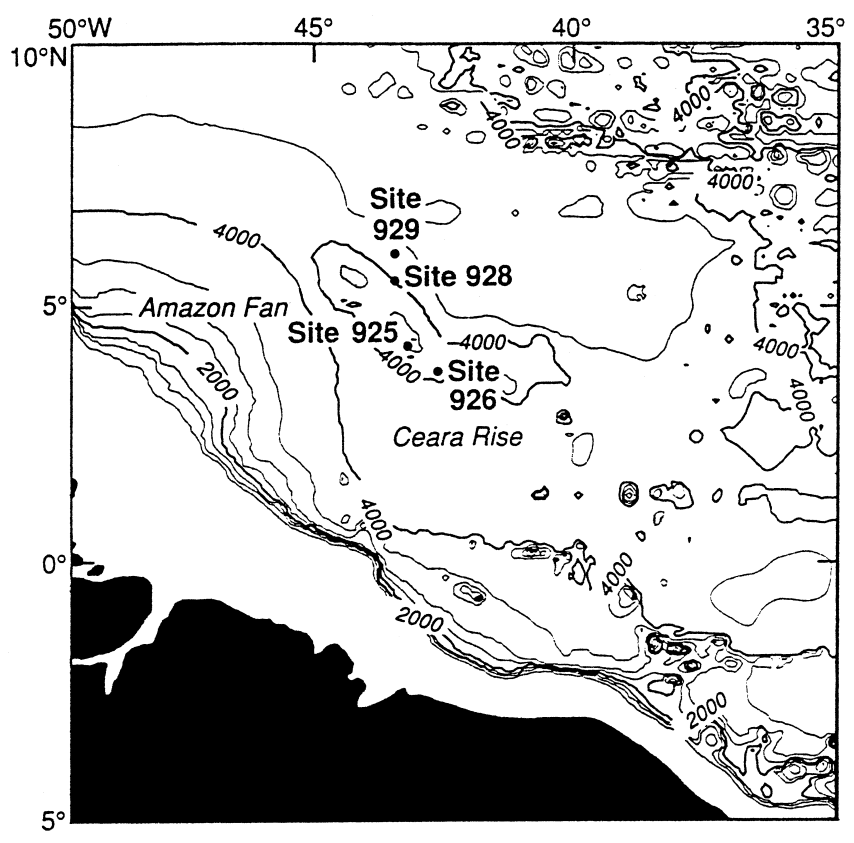

Figure 1. Location of the ODP sites at which Oligocene strata were penetrated during Leg 154.

board composite depth scale. The sediments mainly consist of decimeter-scale alternations of nannofossil chalk and clayey nannofossil chalk in the shallower sites, but clayey nannofossil chalk and nannofossil claystone occur at Site 929. The lower carbonate contents at the deepest site (929) reflect greater carbonate dissolution on the seafloor. Shipboard and post-cruise biostratigraphic studies were conducted at high resolution (samples from between 0.25 and $1.5 \mathrm{~m}$ ), so that most uppermost and lowest occurrence levels are constrained to within a few meters (Curry, Shackleton, Richter, et al., 1995; Pearson and Chaisson, this volume). No magnetic reversal stratigraphy could be recovered.

The percentage reflectance of 550-nm light was recorded onboard ship at $10-\mathrm{cm}$ intervals at Site 925 , and at $5-\mathrm{cm}$ intervals at the three other localities. Magnetic suceptibility was measured aboard at 10 $\mathrm{cm}$. To use records with the same stratigraphic resolution at all sites for this study, magnetic susceptibility was remeasured post-cruise on the split cores at $5 \mathrm{~cm}$ throughout the Oligocene part of Hole 925A using a Bartington Instruments contact probe (Weedon, this volume). Magnetic susceptibility and reflectance are strongly inversely correlated (Fig. 2). This relationship reflects a predominant control on both parameters by the relative concentrations of carbonate and noncarbonate minerals (Curry, Shackleton, Richter, et al., 1995). A pronounced decimeter- to meter-scale cyclicity is apparent throughout the pelagic Oligocene sediments recovered during Leg 154. However, at certain horizons, there are centimeter to decimeter intervals of carbonate turbidites and grain flows and meter-scale intervals of slumped pelagic sediments. The locations of these redeposited sediments are listed in table 2 of "Leg 154 Synthesis" chapter in Curry, Shackleton, Richter, et al. (1995). In addition, in Cores 154-925A$23 \mathrm{R}$ and $24 \mathrm{R}$ there is evidence for faulting at the Oligocene/Miocene boundary from the presence of abundant dip-slip slickensides and sharp, inclined color-breaks.

\section{SPECTRAL ANALYSIS}

The records of percentage reflectance from Holes 926B, 928B, and 929A, and of magnetic susceptibility from Hole 925A were used as time series for spectral analysis. The spectral analysis was used to test for regular sedimentary cycles in the depth domain (not time). The factors that can affect the relationship between time and depth and the implications for depth-domain spectral analysis are fairly well understood (Weedon, 1989; Herbert, 1994). Evidence for significant regular cyclicity in depth can be taken as evidence for a regular cycle in time (Sander, 1936) and, if dating is possible, orbital-climatic control of sedimentation can sometimes be inferred (Weedon, 1993; Schwarzacher, 1993).

Where turbidites or slumps occur, the relevant data were subtracted from the series (Fig. 2). Similarly, the faulted interval at Site 925 was not analyzed. Each spectrum was based on pairs of adjacent cores whenever the nominal coring gap between them was less than $1.0 \mathrm{~m}$. Where larger gaps occurred, data from single cores were used. When the removal of redeposited sediments substantially reduced the remaining length of a core, data from three rather than two cores were combined. Thus, the series analyzed typically consisted of 150-400 values (at 5-cm intervals). The spectra themselves were estimated using the Fast Fourier Transform, following linear detrending, with three applications of a three-point Hanning spectral window $\left(8^{\circ}\right.$ of freedom; Priestley, 1981). The position of the background spectrum was located by assuming red noise for the low-frequency half of the spectrum and using a robust least-squares linear regression on the log-transformed estimates. Approximate one-sided confidence levels were derived from the background spectrum. The robust least squares method (Press et al., 1986) allows estimation of the spectral background by treating large spectral peak values as outliers. Because of the bias of the spectrum (Priestley, 1981), this procedure tends to underestimate the significance of spectral peaks at very low frequencies.

Of the 56 spectra generated, 16 with the highest resolution from throughout each hole have been illustrated in Figure 3 in addition to the pair shown in Figure 2. In the majority of cases, a single significant spectral peak was found corresponding to cycles with wavelengths of 60 to $130 \mathrm{~cm}$ (Table 1). In all the other cases, there are additional secondary peaks corresponding to cyclicity of close to half the wavelength of the dominant cycles, although these are of much lower power (for data from 728 to $745 \mathrm{~m}$ below seafloor [mbsf] in Hole 925A, see Fig. 3).

\section{SEDIMENTATION RATES AND CYCLE PERIODS}

The similarity of the spectra strongly implies that a single environmental factor affected sedimentation across the Ceara Rise during the Oligocene. In most cases, there is a comparatively small change in the wavelength of cyclicity between pairs of cores (Fig. 2). This is most plausibly interpreted as indicating small changes in sedimentation rates rather than a change in the period of the environmental variations. Although the cause of the variations in carbonate contents requires further study, one can say at this point that it relates to productivity, siliciclastic dilution, and/or carbonate dissolution (Pearson et al., this volume; Weedon and Shackleton, this volume). The occasional presence of a cyclicity with about half the wavelength of the dominant cycle may indicate that the dominant component corresponds to the orbital-obliquity cycle and the secondary component the orbital-precession cycle. Alternatively, in some cases the secondary peak may relate to the second harmonic of the dominant cycle; that is, the main oscillations are not perfectly sinusoidal. Such harmonics are common in spectra of time series from the depth domain (Weedon, 1989).

Berger and Loutre (1994) estimated that the period of the obliquity cycle, currently $41,000 \mathrm{yr}$, was $39,381 \mathrm{yr}$ at $72 \mathrm{Ma}$. Accordingly, the obliquity period would have changed only slightly from 40,242 $\mathrm{yr}$ at the start of the Oligocene to 40,467 yr at the end. However, different factors used for the calculations yield a period of $39,280 \mathrm{yr}$ at $72 \mathrm{Ma}$ (Berger and Loutre, 1994). In view of this uncertainty, and given the much larger errors associated with determining sedimenta- 

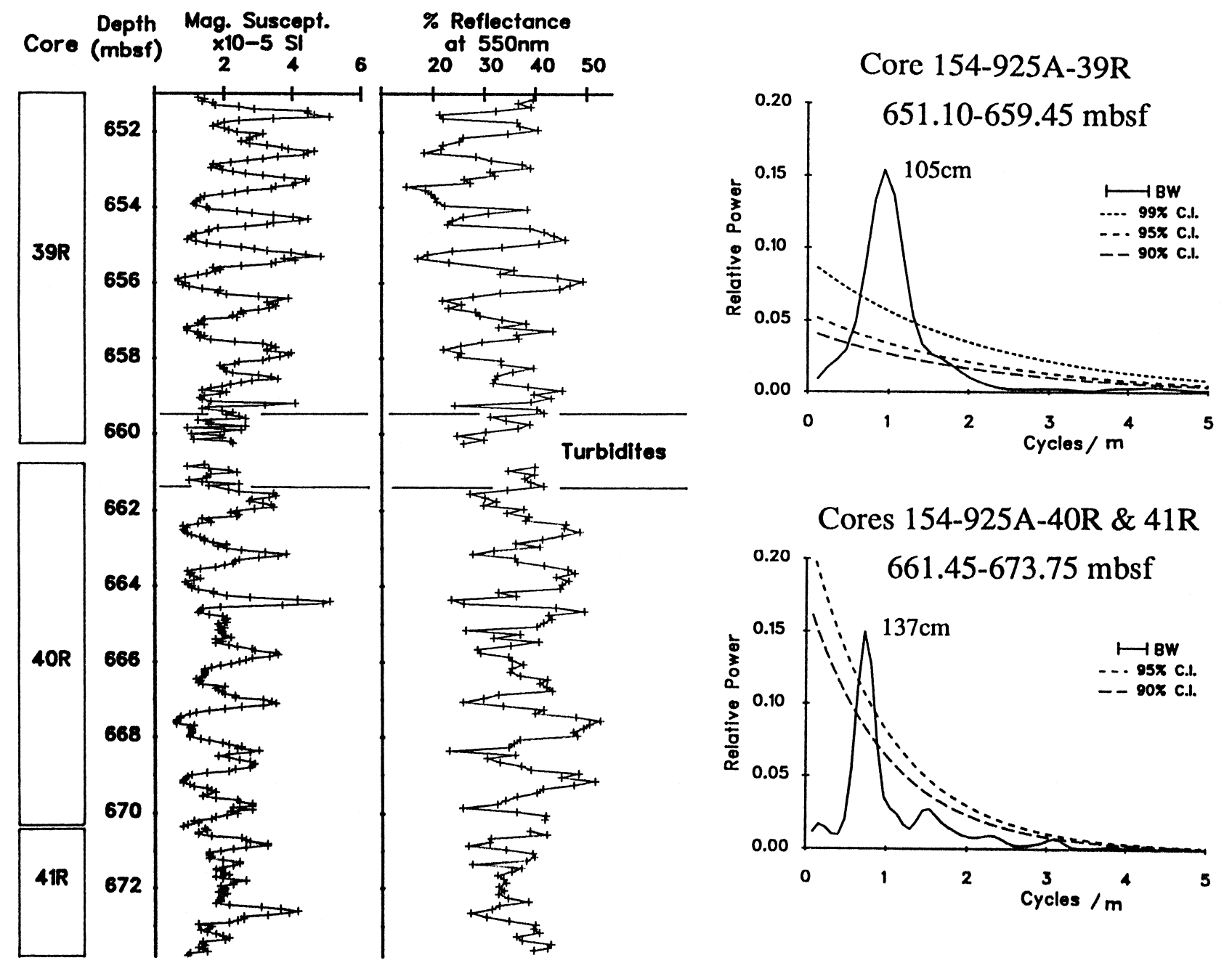

Figure 2. Magnetic susceptibility (MS) and 550-nm light reflectance variations in Cores 154-925A-39R through 41R. These parameters record carbonate variations in these largely pelagic sediments. The sedimentary cycles are interrupted at about $660 \mathrm{mbsf}$ by an interval of turbidites. After removing the values associated with the turbidites, the MS data were used to generate the power spectra shown on the right. On all the spectra in this paper, $\mathrm{BW}=$ bandwidth and CI $=$ onesided confidence interval. The spectra for the MS data are both dominated by a single statistically significant spectral peak, indicating a single regular sedimentary cycle in depth. The wavelengths of the sedimentary cycles indicated by the spectral peaks have been shown. The difference in wavelength of the cyclicity in Core 154-925A-39R and in Cores 154-925A-40R and 41R, detected on the spectra and visible in the time series, is most simply interpreted as resulting from changing (post-compaction) pelagic sedimentation rates.

ry cycle wavelengths discussed later, a rounded figure of 40,000 yr for the period of Oligocene obliquity variations has been adopted here (i.e., a difference of less than $1 \%$ from the estimated mean value). The corresponding periods of the precession and the short eccentricity cycles were about 20,800 and 100,000 yr (Berger and Loutre, 1994).

To test the hypothesis that the dominant sedimentary cycle corresponds to obliquity, sedimentation rates were calculated for the pelagic intervals by dividing the wavelengths in Table 1 by 40,000 yr. Each spectral peak is associated with an error defined by the bandwidth, so the maximum and minimum possible sedimentation rates can be calculated using the frequencies lying half a bandwidth away from each spectral peak. Net sedimentation rates have also been illustrated in Figure 4. It should be noted that the Oligocene is regarded as one of the more problematic intervals for both nannofossil and planktonic foraminifer biostratigraphy. Curry, Shackleton, Richter, et al. (1995) selected a subset of biostratigraphic datum levels to use as tie points for sedimentation rate calculations. These datum levels are considered to be (1) most reliably calibrated, (2) less ambiguous than others taxonomically, and (3) most easily identified on the Ceara Rise, given the moderate dissolution and recrystallization of certain taxa.

There are several reasons why the pelagic sedimentation rates (as inferred from the cyclostratigraphy) and the net sedimentation rates (as inferred from the biostratigraphy) might differ. The pelagic rates would be wrong if the main sedimentary cyclicity is not associated with the obliquity cycle. For instance, an average cycle wavelength of $1.00 \mathrm{~m}$ would imply a pelagic sedimentation rate of $25 \mathrm{~m} / \mathrm{m}$.y. if related to the obliquity cycle, but only $10 \mathrm{~m} / \mathrm{m}$.y. if associated with the eccentricity cycle or $48 \mathrm{~m} / \mathrm{m}$.y. if associated with the precession cycle. The net rates include the intervals of the redeposited sediments (yielding higher rates than the pelagic rates) and the effect of the fault at Site 925. There are errors in the net rates because they were calculated using the mid-points of the stratigraphic uncertainty in the location of each individual biostratigraphic event. In addition, the absolute ages used for these events may be in error.

Despite all these possible sources of difference, there is generally good agreement between the two types of sedimentation rate esti- 

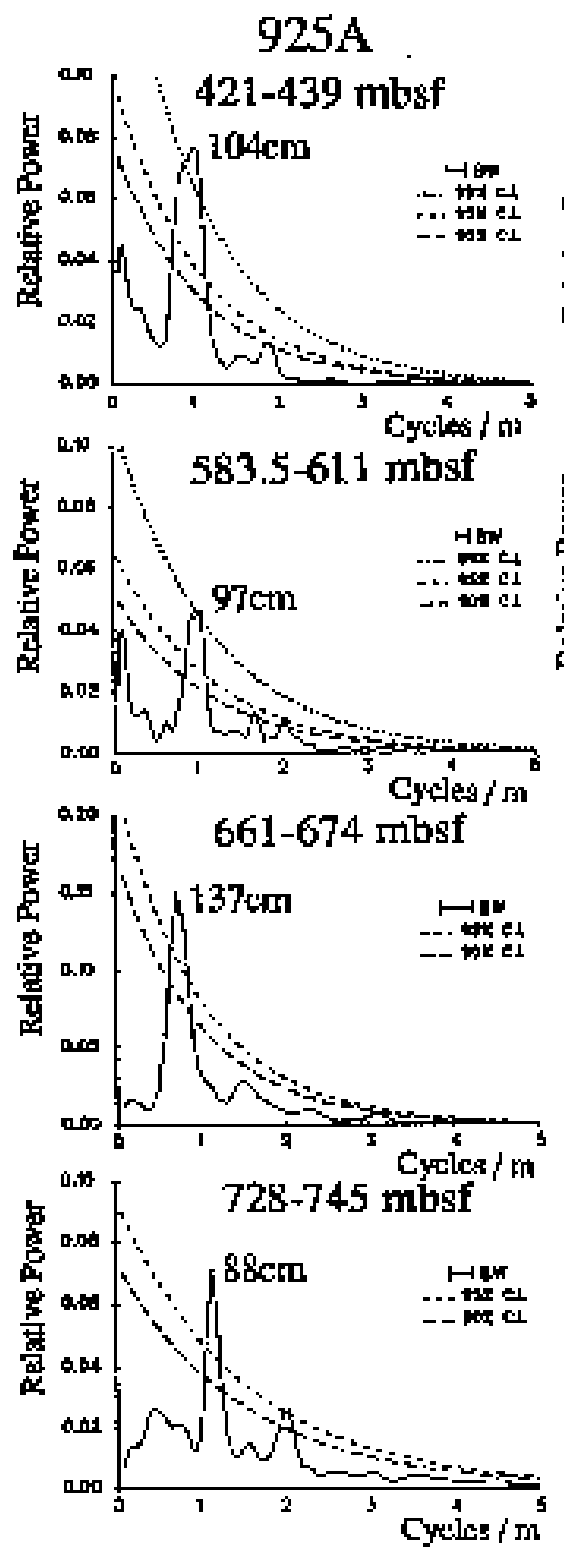

926B
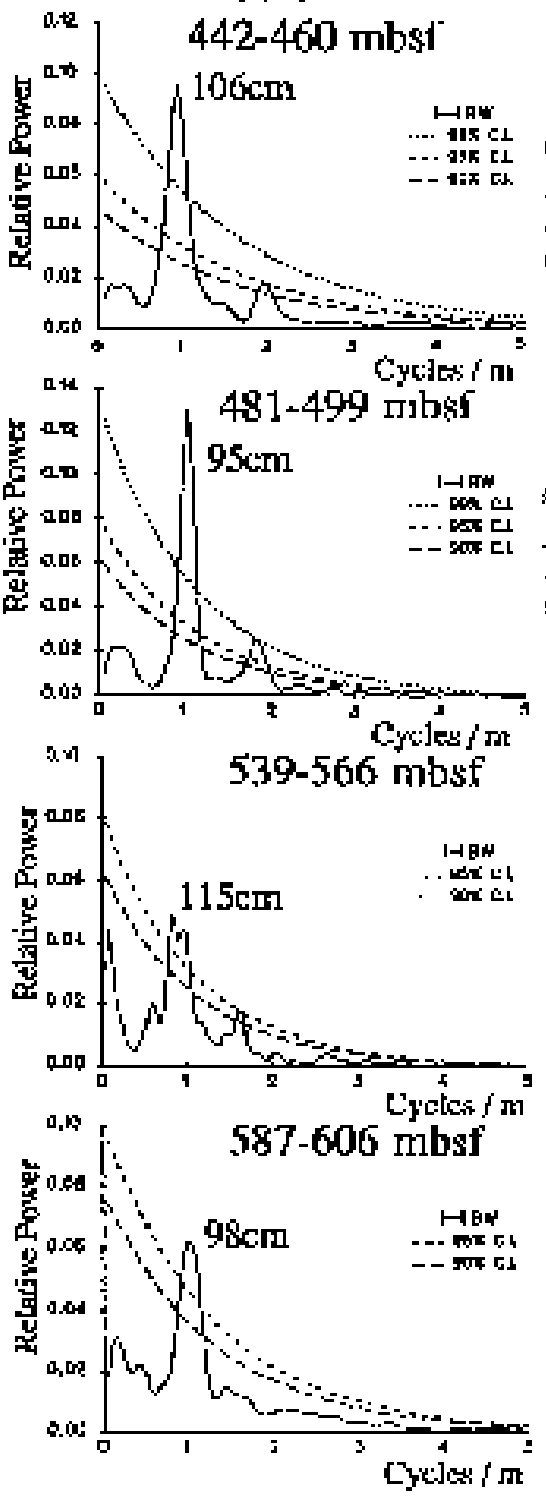

$928 \mathrm{~B}$
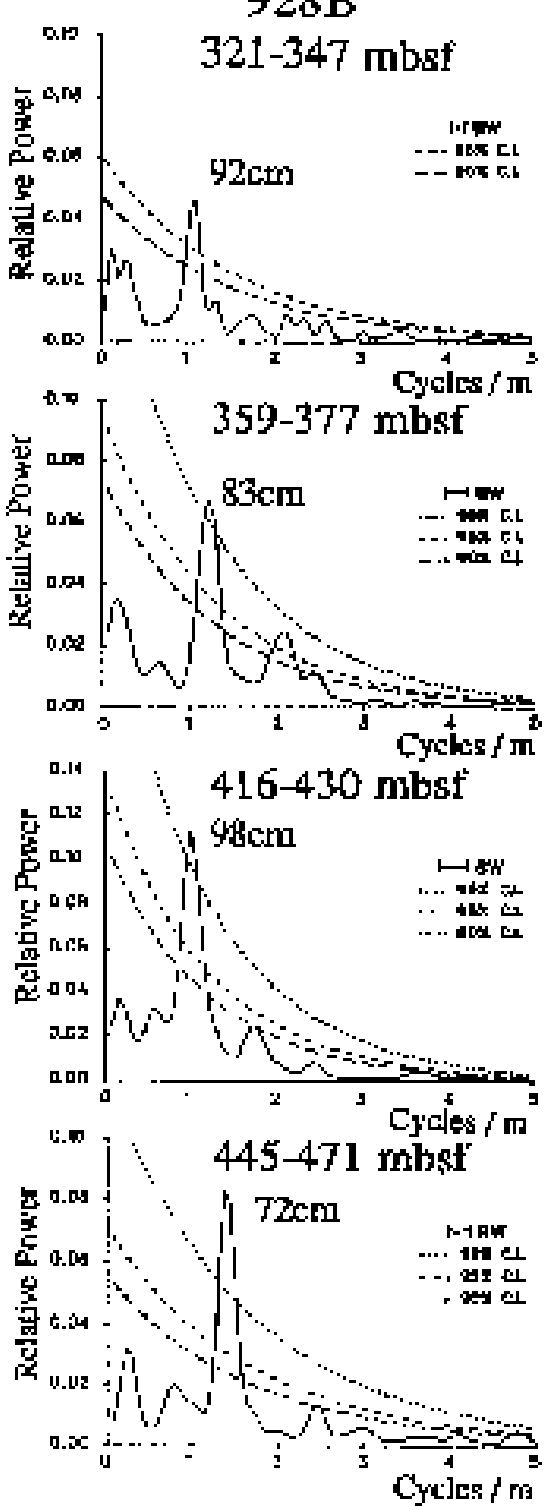
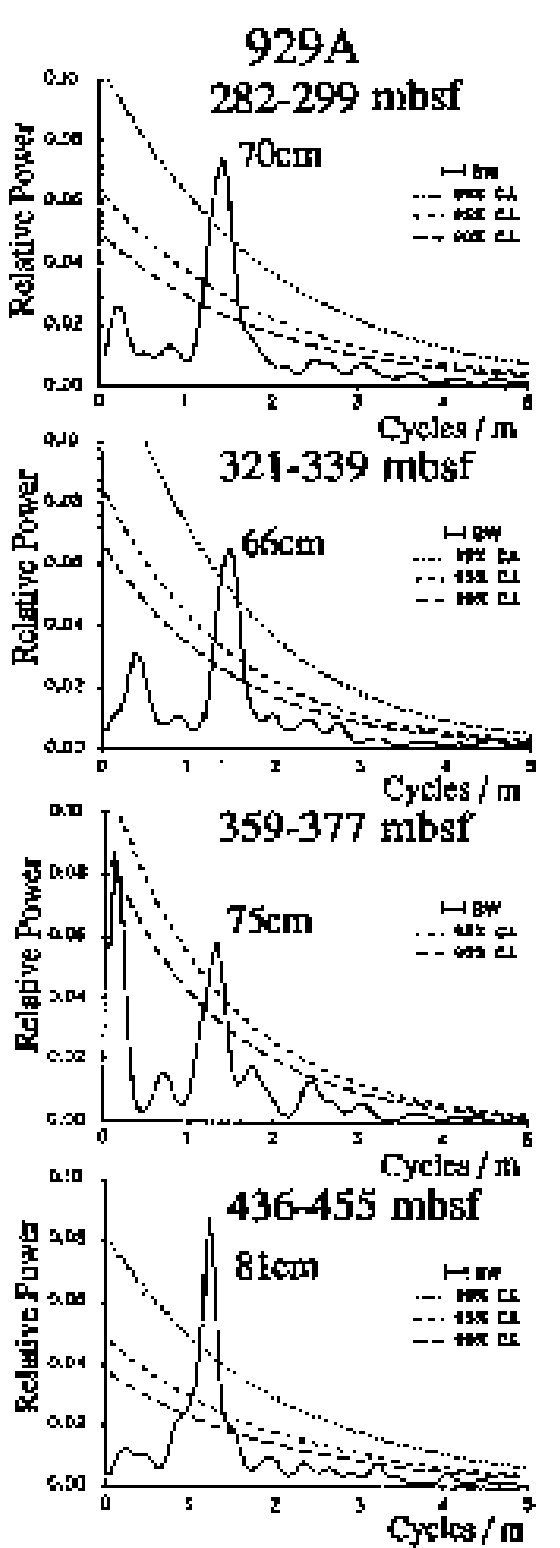

Figure 3. Selected power spectra from time series of magnetic susceptibility at Site 925 and from reflectance at the other sites. In each case, there is one clearly dominant spectral peak representing cyclicity with a wavelength of $60-130 \mathrm{~cm}$. These cycles are thought to record the orbital obliquity variations. On a few spectra there are significant small secondary peaks (unlabeled), which may relate to the precession cycle. 
Table 1. Spectral analysis data and pelagic sedimentation rates assuming a 40-k.y. period for the main cyclicity.

\begin{tabular}{|c|c|c|c|c|c|}
\hline $\begin{array}{l}\text { Interval of } \\
\text { time series }\end{array}$ & $\begin{array}{l}\text { Core depths } \\
\text { (mbsf) }\end{array}$ & $\begin{array}{l}\text { No. points in } \\
\text { time series }\end{array}$ & $\begin{array}{c}\text { Wavelength } \\
\text { signif. peaks }(\mathrm{m})\end{array}$ & $\begin{array}{l}\text { Bandwidth } \\
\text { (cycles/m) }\end{array}$ & $\begin{array}{l}\text { Sedimentation } \\
\text { rate }(\mathrm{m} / \mathrm{m} . \mathrm{y} .)\end{array}$ \\
\hline $\begin{array}{l}\text { 154-925A- } \\
15 \mathrm{R}, 16 \mathrm{R} \\
17 \mathrm{R}, 18 \mathrm{R} \\
\text { 22R } \\
\text { 26R, 27R } \\
30 \mathrm{R}, 31 \mathrm{R} \\
32 \mathrm{R}, 33 \mathrm{R}, 34 \mathrm{R} \\
36 \mathrm{R} \\
38 \mathrm{R} \\
39 \mathrm{R} \\
40 \mathrm{R}, 41 \mathrm{R} \\
42 \mathrm{R}, 43 \mathrm{R}, 44 \mathrm{R} \\
\text { 45R, 46R, 47R } \\
48 \mathrm{R}, 49 \mathrm{R} \\
\text { 50R, 51R } \\
\text { 52R, 53R-3 } \\
\text { 53R-3, 54R } \\
\text { 55R, 56R }\end{array}$ & $\begin{array}{l}421.25-438.75 \\
438.90-455.05 \\
487.10-497.00 \\
525.60-544.60 \\
564.20-576.65 \\
583.50-611.05 \\
622.10-631.80 \\
641.40-651.05 \\
651.10-659.45 \\
661.45-673.75 \\
680.55-696.30 \\
699.30-726.15 \\
727.90-744.55 \\
746.15-753.25 \\
757.00-770.90 \\
770.95-783.80 \\
786.05-788.55\end{array}$ & $\begin{array}{l}176 \\
337 \\
199 \\
386 \\
255 \\
562 \\
195 \\
194 \\
168 \\
247 \\
296 \\
552 \\
334 \\
164 \\
273 \\
243 \\
250\end{array}$ & $\begin{array}{l}1.035 \\
1.296 \\
0.995 \\
1.206^{\mathrm{a}} \\
1.275 \\
0.969 \\
0.975 \\
1.213 \\
1.050 \\
1.372 \\
0.925 \\
0.920 \\
0.879 \\
1.171 \\
1.365 \\
0.380 \\
0.403\end{array}$ & $\begin{array}{l}0.2519 \\
0.2631 \\
0.4455 \\
0.2297 \\
0.3477 \\
0.1578 \\
0.4547 \\
0.4570 \\
0.5277 \\
0.3589 \\
0.2995 \\
0.1606 \\
0.2654 \\
0.5406 \\
0.3248 \\
0.3649 \\
0.3546\end{array}$ & $\begin{array}{r}25.9 \\
32.4 \\
24.9 \\
30.2 \\
31.9 \\
24.2 \\
24.4 \\
30.3 \\
26.3 \\
34.3 \\
23.1 \\
23.0 \\
22.0 \\
29.3 \\
34.1 \\
9.5 \\
10.1\end{array}$ \\
\hline $\begin{array}{l}\text { 154-926B- } \\
38 \mathrm{X}, 39 \mathrm{X} \\
40 \mathrm{X}, 41 \mathrm{X} \\
42 \mathrm{X}, 43 \mathrm{X} \\
44 \mathrm{X}, 45 \mathrm{X} \\
46 \mathrm{X}, 47 \mathrm{X} \\
48 \mathrm{X}, 49 \mathrm{X} \\
50 \mathrm{X}, 51 \mathrm{X} \\
52 \mathrm{X}, 53 \mathrm{X} \\
54 \mathrm{X}, 55 \mathrm{X} \\
56 \mathrm{X}, 57 \mathrm{X} \\
58 \mathrm{X}, 59 \mathrm{X}, 60 \mathrm{X} \\
61 \mathrm{X} \\
62 \mathrm{X} \\
63 \mathrm{X}, 64 \mathrm{X}\end{array}$ & $\begin{array}{l}345.85-364.65 \\
365.15-381.31 \\
384.15-402.20 \\
403.45-422.20 \\
422.85-441.15 \\
442.15-460.05 \\
461.50-480.40 \\
480.55-498.80 \\
499.95-518.40 \\
519.25-537.95 \\
538.55-565.55 \\
567.65-574.95 \\
577.25-582.25 \\
586.95-605.85\end{array}$ & $\begin{array}{r}364 \\
304 \\
341 \\
356 \\
344 \\
341 \\
356 \\
361 \\
349 \\
355 \\
507 \\
143 \\
98 \\
359\end{array}$ & $\begin{array}{l}1.071 \\
1.267 \\
1.312 \\
1.112 \\
1.229 \\
1.066 \\
1.047 \\
0.950 \\
0.969 \\
0.934^{\mathrm{a}} \\
1.152 \\
1.021 \\
0.980 \\
0.997\end{array}$ & $\begin{array}{l}0.2436 \\
0.2916 \\
0.2600 \\
0.2490 \\
0.2577 \\
0.2600 \\
0.2490 \\
0.2456 \\
0.2540 \\
0.2497 \\
0.1749 \\
0.6200 \\
0.9047 \\
0.2470\end{array}$ & $\begin{array}{l}26.8 \\
31.7 \\
32.8 \\
27.8 \\
30.7 \\
26.7 \\
26.2 \\
23.8 \\
24.2 \\
23.4 \\
28.8 \\
25.5 \\
24.5 \\
24.9\end{array}$ \\
\hline $\begin{array}{l}\text { 154-928B- } \\
\text { 31X, 32X } \\
33 \mathrm{X}, 34 \mathrm{X} \\
35 \mathrm{X}, 36 \mathrm{X}, 37 \mathrm{X} \\
38 \mathrm{X} \\
39 \mathrm{X}, 40 \mathrm{X} \\
41 \mathrm{X}, 42 \mathrm{X} \\
43 \mathrm{X}, 44 \mathrm{X} \\
\text { 45X, 46X-4c } \\
46 \mathrm{X}-4,47 \mathrm{X} \\
\text { 48X, 49X, 50X } \\
\text { 51X, 52X } \\
\text { 54X, 55X }\end{array}$ & $\begin{array}{l}281.55-298.75 \\
300.95-320.10 \\
320.45-347.35 \\
349.35-357.10 \\
358.95-376.80 \\
377.85-395.90 \\
396.85-415.65 \\
416.05-429.54 \\
429.59-442.75 \\
445.05-470.50 \\
476.25-484.50 \\
502.95-516.70\end{array}$ & $\begin{array}{l}313 \\
363 \\
514 \\
151 \\
330 \\
316 \\
360 \\
254 \\
250 \\
330 \\
156 \\
263\end{array}$ & $\begin{array}{l}0.782 \\
0.955 \\
0.918 \\
0.839 \\
0.825 \\
0.988 \\
0.947 \\
0.977 \\
0.833 \\
0.717 \\
0.780 \\
0.774\end{array}$ & $\begin{array}{l}0.2833 \\
0.2442 \\
0.1725 \\
0.5871 \\
0.2687 \\
0.2806 \\
0.2463 \\
0.3491 \\
0.3546 \\
0.2687 \\
0.5683 \\
0.3371\end{array}$ & $\begin{array}{l}19.6 \\
23.9 \\
23.0 \\
21.0 \\
20.6 \\
24.7 \\
23.7 \\
24.4 \\
20.8 \\
17.9 \\
19.5 \\
19.4\end{array}$ \\
\hline $\begin{array}{l}\text { 154-929A- } \\
\text { 29X, 30X } \\
31 \mathrm{X}, 32 \mathrm{X} \\
33 \mathrm{X}, 34 \mathrm{X} \\
35 \mathrm{X}, 36 \mathrm{X} \\
37 \mathrm{X}, 38 \mathrm{X} \\
39 \mathrm{X}, 40 \mathrm{X} \\
41 \mathrm{X} \\
43 \mathrm{X} \\
44 \mathrm{X}, 45 \mathrm{X}, 46 \mathrm{X} \\
47 \mathrm{X}, 48 \mathrm{X} \\
49 \mathrm{X}, 50 \mathrm{X} \\
51 \mathrm{X}, 52 \mathrm{X}, 53 \mathrm{X} \\
54 \mathrm{X}^{\mathrm{d}}\end{array}$ & $\begin{array}{l}262.25-281.30 \\
281.65-298.75 \\
301.05-320.00 \\
320.45-339.40 \\
339.75-358.20 \\
359.05-376.55 \\
378.15-384.25 \\
397.45-404.95 \\
407.45-430.20 \\
436.15-454.75 \\
455.35-474.40 \\
474.65-497.90 \\
503.25-509.40\end{array}$ & $\begin{array}{l}362 \\
324 \\
355 \\
356 \\
347 \\
316 \\
117 \\
113 \\
167 \\
355 \\
354 \\
416 \\
119\end{array}$ & $\begin{array}{l}0.624 \\
0.704 \\
0.683 \\
0.659 \\
0.826 \\
0.752 \\
0.975 \\
0.807 \\
0.928 \\
0.807 \\
0.885 \\
0.800 \\
-\end{array}$ & $\begin{array}{l}0.2441 \\
0.2736 \\
0.2497 \\
0.2490 \\
0.2555 \\
0.2806 \\
0.7578 \\
0.7846 \\
0.5309 \\
0.2498 \\
0.2505 \\
0.2131 \\
0.7450\end{array}$ & $\begin{array}{l}15.6 \\
17.6 \\
17.1 \\
16.5 \\
20.7 \\
18.8 \\
24.4 \\
20.2 \\
23.2 \\
20.2 \\
22.1 \\
20.0 \\
-\end{array}$ \\
\hline
\end{tabular}

Notes: "Core depths" indicates the depth from which time series data were obtained even though data from redeposited intervals were subtracted before spectral analysis. The locations of redeposited sediment intervals (turbidites and slumps) are listed in table 2 of "Leg 154 Synthesis" chapter in Curry, Shackleton, Richter, et al. (1995).

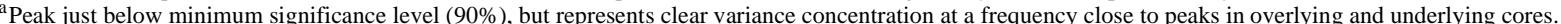

${ }^{\mathrm{b}}$ In Core 154-925A-53R, there is an abrupt change in average carbonate contents and the scale of the cyclicity at 770.90 mbsf (interpreted as a hiatus). As a result, data from this core has been split into two time series above and below this level.

${ }^{\mathrm{c}}$ Hiatus inferred at $429.56 \mathrm{mbsf}$ at Section $154-928 \mathrm{~B}-46 \mathrm{X}-4,50 \mathrm{~cm}$.

${ }^{\mathrm{d}}$ No peak corresponding to cyclicity between 0.6 and $1.0 \mathrm{~m}$ (time series may include unidentified slumped material).

mates for Sites 926,928 , and 929. The sedimentation rates estimated from the cyclicity usually change more smoothly than the net rates. However, in the lower Oligocene of Site 928, the large difference probably partly reflects the effect of the intervals of redeposited sediment on the net rates. In general, all sedimentation rates are highest at the shallower sites where carbonate dissolution was probably less.

There are major disagreements in the two types of sedimentation rate estimates for Site 925 . The pelagic rates change more gradually than the net rates. This suggests that the positions or ages for the bio- stratigraphic events are more likely to be in error. Assuming that the same environmental factor accounts for all the cyclicity on the Ceara Rise (e.g., the obliquity signal), the disagreement in the upper Oligocene at Site 925 is most likely to relate to the occurrence of the faulted interval near the Oligocene/Miocene boundary. Because at this level the pelagic rates are greater than the net rate, there must be missing strata, thus implying normal fault displacement. In the lower Oligocene of Site 925, the principal disagreement occurs at the same interval as the discrepancy at Site 928 . In both cases, the unusually 

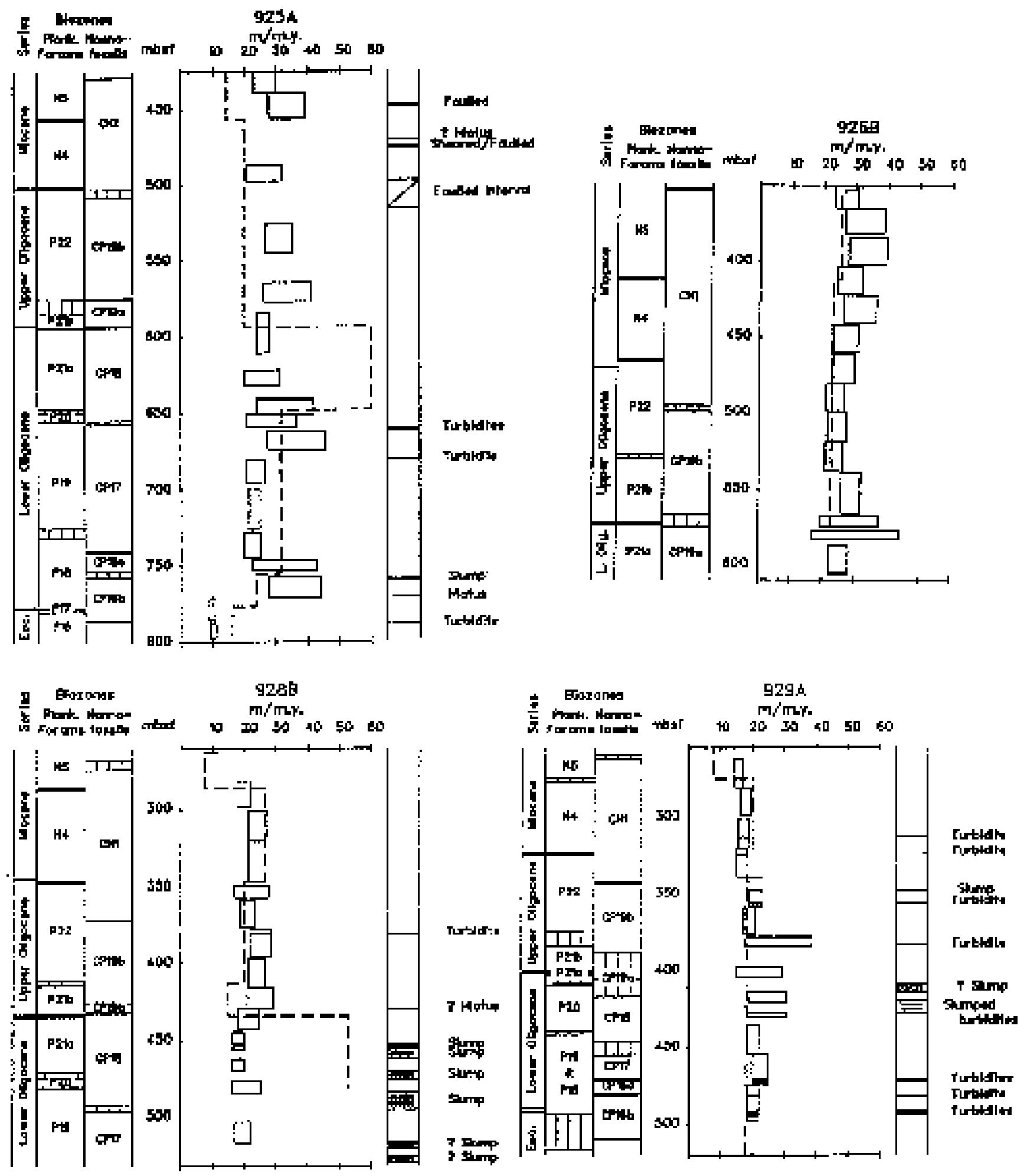

Figure 4. Sedimentation rate estimates (net rates) based on biostratigraphic events (dashed lines) and estimated from sedimentary cycle wavelengths (pelagic rates) from the spectral analyses (boxes). In all cases it has been assumed that the meter-scale sedimentary cycles had periods equal to the orbital-obliquity cycle or 40,000 yr (Table 1). The height of each box shows the cored intervals yielding the time series used for spectral analysis. The width of the boxes shows estimates of the maximum and minimum possible pelagic sedimentation rates based on the uncertainty in cycle wavelengths defined by the spectral bandwidths. For example, between 438.90 and $455.05 \mathrm{mbsf}$ (Cores 154-925A-17R and 18R), the average wavelength of the main cycles according to the spectrum is $1.30 \mathrm{~m}$ and the bandwidth 0.263 cycles per $\mathrm{m}$ (Table 1). Therefore, the mean sedimentation rate is $1.30 / 0.04=32.5 \mathrm{~m} / \mathrm{m} . \mathrm{y}$. The minimum cycle wavelength using the bandwidth is $1 /[(1 / 1.30)+(0.5 \times 0.263)]=1.11 \mathrm{~m}$. This implies a minimum possible sedimentation rate of $27.7 \mathrm{~m} / \mathrm{m}$.y. Likewise, the maximum cycle wavelength is $1 /[(1 / 1.30)-(0.5 \times 0.263)]=1.57 \mathrm{~m}$, indicating a maximum rate of $39.2 \mathrm{~m} / \mathrm{m} . \mathrm{y}$. 
high net sedimentation rate estimates are associated with the boundaries of Biozones P21a and P20. This might indicate an error in the ages of these biostratigraphic events (discussed later).

As indicated earlier, if the main cyclicity in the Oligocene of the Ceara Rise is related to the eccentricity cycle, then the pelagic sedimentation rates would be reduced by a factor of 2.5 . On the other hand, precession cycles would produce rates that were higher by a factor of nearly 2 . In both of these alternative scenarios, very few of the estimated pelagic sedimentation rates at Sites 926, 928, and 929 would agree with the net sedimentation rates. In addition, on many power spectra there are spectral peaks representing smaller amplitude cycles with wavelengths about $50 \%$ of the main cycles (Fig. 3). The smaller cycles are readily identified with the precession cycle. Accordingly, we conclude that the main sedimentary cyclicity records the obliquity signal.

\section{CUMULATIVE TIME}

With a known period for the sedimentary cyclicity, interval dating can be attempted for the Oligocene. A common reference datum level is needed to allow comparison of results between sites. Berggren et al. (1995) used the lowest occurrence of the planktonic foraminifer Paragloborotalia kugleri to recognize the base of the Miocene. Not only is this datum difficult to locate consistently at high resolution, because $P$. kugleri evolved by gradual transition from Paragloborotalia pseudokugleri, but it is also less tightly constrained by sampling on the Ceara Rise than the top of Sphenolithus delphix. Hence, the lowermost sample in which S. delphix was found has been adopted here as the reference datum and a proxy for the base of the Miocene.

The cumulative time below the top of $S$. delphix was calculated using the thickness of pelagic sediments penetrated in successive cores and the sedimentation rates in Table 1. It was assumed that the unrecovered intervals between cores would have yielded pelagic sediment except in cases where turbidites were encountered at the base of one core and the top of the next (Fig. 2). The sedimentation rates calculated for the overlying core were used to estimate the time represented by the coring gaps. When, in a few cases, the nominal depth of the base of a core catcher exceeded the depth of the top of the underlying core, the cumulative age was calculated by repositioning the top of the underlying core immediately below the core-catcher sediment to prevent overlapping ages.

This excercise necessarily assumes that sedimentation rates, defined by the average cycle wavelengths obtained from the spectra, remained constant for core pairs (or over intervals of $0.5-1.0 \mathrm{Ma}$ ). This is unlikely to be correct in detail. Nevertheless, the consistency of pelagic sedimentation rates for successive core pairs (Fig. 4) and the well-defined (narrow) spectral peaks, suggest that pelagic sedimentation rates probably varied by less than about $30 \%$ of the mean within cores. The procedure used can be regarded as a first-order estimate of interval durations based on the cyclicity. More refined procedures would be to fix individual reflectance maxima at 40,000-yr intervals (second order) or to tune the signal to the insolation history (third order).

The cumulative time below the top of the Oligocene has been calculated independently for each site and without reference to biostratigraphic events other than the topmost occurrence of S. delphix. The cumulative ages of core tops are listed in Table 2 and the ages of the biostratigraphic events appear in Table 3 . The reflectance time series plotted in cumulative time are illustrated in Figure 5. Because the maximum distance between sites is about $60 \mathrm{~km}$, it is unlikely that the biostratigraphic events are significantly diachronous over the Ceara Rise. Given that most events have been accurately located in the cores, the cumulative ages would be expected to be the same everywhere on the rise.
There is good agreement for the cumulative ages of the bases of foraminifer Biozones N4 and P21b and nannofossil Biozones CN1 and CP19b from the late Oligocene at Sites 926, 928, and 929. The base of Biozone P22 agrees between Sites 928 and 929, but it is problematic at Site 926 (Pearson and Chaisson, this volume). The estimate for the duration of the late Oligocene is much less at Site 925 than elsewhere (Fig. 5). The reason for this is undoubtedly the faulted interval within which the bases of Biozone N4 (top of Biozone P22) and CN1 (top of Sub-biozone CP19b) occur unusually close together. In the mid-Oligocene at Site 926, Biozone CP19a appears to start unusually early, perhaps meriting further biostratigraphic study. In the early Oligocene at Site 929, Biozone P21a is exceptionally short compared with the other sites. This may result from faulting at the top of Core 154-929A-44X where a previously undescribed inclined sharp color break overlies an interval tentatively ascribed on board as a slump. In addition, at this level there were biostratigraphic problems described by Curry, Shackleton, Richter, et al. (1995). At Site 929, the durations of CP18 and CP17 are also very short compared with Sites 925 and 928 . This may indicate further missing strata and/ or that the carbonate dissolution became concentrated at specific levels at this deepest site as microfossil preservation ranged from poor to barren in the older material in the cores of Hole 929A.

\section{COMPOSITE TIME SCALE FOR THE CEARA RISE}

The various discrepancies in the cumulative ages of the biostratigraphic events can be partly resolved by correlation of time series between sites. This was achieved by visually correlating particular peaks and troughs ("tie points") in the percentage reflectance for each core plotted in cumulative time. This method allowed particular core time series to be moved relative to other cores by using coring gaps and not allowing overlap of time series from the same site. No attempt was made to tune the records to a target curve and the data were used without filtering. It was necessary to use the position of the midOligocene biostratigraphic events (e.g., base of Sub-biozone P21b) at Site 925 as a guide to lithostratigraphic correlation based on the reflectance data, in order to remove the apparent offset caused by the faulting. The resulting adjusted ages are described as "composite" here to emphasize the similarity with the more routine production of composite depth scales for several holes at single sites in younger sediments. The reference datum for all localities was the top of the sampling uncertainty range of the topmost occurrence of $S$. delphix in Hole 929A.

During the construction of the composite time scale, coring gaps were avoided. Moving down the holes, a single core from a single site, containing both an old tie point and the next tie point down, was selected. The cumulative time between tie points was then established using Table 1 . The location of each tie point is listed in Table 4. The sum of the cumulative time intervals between tie points yielded the composite time for the new level. From this, the composite time for the top of each core containing the new tie point at all sites could be calculated (Table 2). The positions and composite ages of biostratigraphic events are listed in Table 3. It was not possible to correlate data from the base of Hole 928B (Cores 154-928B-52X through 56X) where there are frequent large slumps (Fig. 4). In Hole 929A, correlation proved impossible below Core 154-929A-43X because of biostratigraphic uncertainties and perhaps missing or condensed strata related to unidentified faults or dissolution horizons. This meant that only data from Site 925 were used for the earliest Oligocene, with the composite ages derived directly from the cumulative ages of this location. This meant that composite ages for the earliest Oligocene included coring gaps (for which there is no direct evidence that the section lacks faulting and/or redeposited sediment). The reflectance data that could be correlated and the information from the 
Table 2. Cumulative and composite ages of core tops and redeposited intervals.

\begin{tabular}{|c|c|c|c|}
\hline Location & $\begin{array}{l}\text { Depth } \\
\text { (mbsf) }\end{array}$ & $\begin{array}{c}\text { Cumulative } \\
\text { age (Ma) }\end{array}$ & $\begin{array}{c}\text { Composite } \\
\text { age (Ma) }\end{array}$ \\
\hline \multicolumn{4}{|l|}{$154-925 \mathrm{~A}-$} \\
\hline Top Core 23R & 500.59 & -0.013 & - \\
\hline Top Core $24 \mathrm{R}$ & 506.30 & 0.217 & - \\
\hline Top Core $26 \mathrm{R}$ & 525.60 & 0.992 & 1.839 \\
\hline Top Core 27R & 535.30 & 1.325 & 2.284 \\
\hline Top Core $28 \mathrm{R}$ & 544.90 & 1.643 & - \\
\hline Top Core 29R & 554.60 & 1.964 & - \\
\hline Top Core $30 \mathrm{R}$ & 564.20 & 2.283 & 3.050 \\
\hline Top Core 31R & 573.80 & 2.595 & 3.422 \\
\hline Top Core $32 \mathrm{R}$ & 583.50 & 2.900 & 3.638 \\
\hline Top Core 33R & 593.10 & 3.305 & 4.054 \\
\hline Top Core $34 \mathrm{R}$ & 602.80 & 3.715 & 4.490 \\
\hline Top Core $35 \mathrm{R}$ & 612.40 & 4.111 & 4.917 \\
\hline Top Core $36 \mathrm{R}$ & 622.10 & 4.512 & 5.306 \\
\hline Top Core $38 \mathrm{R}$ & 641.40 & 5.303 & 6.071 \\
\hline Top Core $39 \mathrm{R}$ & 651.10 & 5.629 & 6.397 \\
\hline Top turbidite in Core $39 \mathrm{R}$ & 659.50 & 5.949 & 6.717 \\
\hline Top Core 40R & 660.80 & 5.949 & 6.717 \\
\hline Base turbidite in Core 40R & 661.38 & 5.949 & 6.717 \\
\hline Top Core 41R & 670.40 & 6.212 & 6.980 \\
\hline Top Core $42 \mathrm{R}$ and turbidite & 680.10 & 6.495 & 7.263 \\
\hline Base turbidite in Core 42R & 680.35 & 6.495 & 7.263 \\
\hline Top Core 43R & 683.10 & 6.614 & 7.382 \\
\hline Top Core 44R & 689.70 & 6.899 & 7.667 \\
\hline Top Core 45R & 699.30 & 7.314 & 8.082 \\
\hline Top Core 46R & 709.00 & 7.744 & 8.512 \\
\hline Top Core 47R & 718.30 & 8.176 & 8.944 \\
\hline Top Core 48R & 727.90 & 8.594 & 9.361 \\
\hline Top Core 49R & 737.60 & 9.041 & 9.809 \\
\hline Top Core 50R & 746.15 & 9.431 & 10.199 \\
\hline Top Core 51R & 747.10 & 9.468 & 10.236 \\
\hline Top Core $52 \mathrm{R}$ & 757.00 & 9.806 & 10.574 \\
\hline Top slump in Core $52 \mathrm{R}$ & 758.75 & 9.858 & 10.625 \\
\hline Base slump in Core $52 \mathrm{R}$ & 759.10 & 9.858 & 10.625 \\
\hline Top Core 53R & 766.60 & 10.085 & 10.853 \\
\hline Hiatus in Core $53 \mathrm{R}$ & 770.95 & 10.212 & 10.980 \\
\hline Top 54R & 776.30 & 10.776 & 11.543 \\
\hline Top 55R & 786.05 & 11.830 & 12.598 \\
\hline Top turbidite in Core 55R & 788.60 & 12.083 & 12.851 \\
\hline Base turbidite in Core $55 \mathrm{R}$ & 788.65 & 12.083 & 12.851 \\
\hline Top 56R & 795.65 & 12.778 & 13.944 \\
\hline Top slump in Core 56R & 797.87 & 13.001 & 13.769 \\
\hline Base slump in Core 56R & 802.30 & 13.440 & 14.208 \\
\hline \multicolumn{4}{|l|}{ 154-926B- } \\
\hline Top Core 50X & 461.50 & -0.313 & -0.276 \\
\hline Top Core 51X & 471.05 & 0.064 & 0.092 \\
\hline Top Core $52 \mathrm{X}$ & 480.50 & 0.425 & 0.450 \\
\hline Top Core 53X & 490.20 & 0.839 & 0.860 \\
\hline Top Core $54 \mathrm{X}$ & 499.90 & 1.247 & 1.250 \\
\hline Top Core $55 \mathrm{X}$ & 509.50 & 1.652 & 1.638 \\
\hline Top Core 56X & 519.20 & 2.052 & 2.022 \\
\hline Top Core 57X & 528.90 & 2.472 & 2.478 \\
\hline Top Core $58 \mathrm{X}$ & 538.50 & 2.885 & 2.830 \\
\hline Top Core 59X & 548.20 & 3.222 & 3.141 \\
\hline Top Core $60 \mathrm{X}$ & 557.90 & 3.561 & 3.491 \\
\hline Top Core $61 \mathrm{X}$ & 567.60 & 3.898 & 3.835 \\
\hline Top Core $62 \mathrm{X}$ & 577.20 & 4.274 & 4.206 \\
\hline Top Core $63 \mathrm{X}$ & 586.90 & 4.670 & 4.410 \\
\hline Top Core $64 \mathrm{X}$ & 596.50 & 5.066 & 4.967 \\
\hline \multicolumn{4}{|l|}{ 154-928B- } \\
\hline Top Core $37 \mathrm{X}$ & 339.70 & -0.212 & -0.241 \\
\hline Top Core $38 \mathrm{X}$ & 349.30 & 0.206 & 0.118 \\
\hline Top Core $39 \mathrm{X}$ & 358.90 & 0.664 & 0.572 \\
\hline Top Core 40X & 368.20 & 1.115 & 0.993 \\
\hline Top Core 41X & 377.80 & 1.580 & 1.465 \\
\hline Top turbidite in Core $41 \mathrm{X}$ & 380.84 & 1.703 & 1.588 \\
\hline Base turbidite in Core $41 \mathrm{X}$ & 381.14 & 1.703 & 1.588 \\
\hline Top Core 42R & 387.50 & 1.960 & 1.857 \\
\hline Top Core 43R & 396.80 & 2.339 & 2.276 \\
\hline Top Core 44R & 406.40 & 2.745 & 2.713 \\
\hline Top Core $45 \mathrm{X}$ & 416.00 & 3.160 & 3.084 \\
\hline Top Core 46X & 425.70 & 3.562 & 3.546 \\
\hline Hiatus in Core $46 \mathrm{X}$ & 429.57 & 3.720 & 3.719 \\
\hline Top Core 47X & 435.30 & 4.007 & 3.980 \\
\hline Top Core $48 \mathrm{X}$ & 445.00 & 4.473 & 4.454 \\
\hline
\end{tabular}

\begin{tabular}{|c|c|c|c|}
\hline Location & $\begin{array}{l}\text { Depth } \\
\text { (mbsf) }\end{array}$ & $\begin{array}{l}\text { Cumulative } \\
\text { age (Ma) }\end{array}$ & $\begin{array}{c}\text { Composite } \\
\text { age (Ma) }\end{array}$ \\
\hline Top slump in Core $48 \mathrm{X}$ & 452.54 & 4.894 & 4.873 \\
\hline Base slump in Core $48 \mathrm{X}$ & 453.90 & 4.894 & 4.873 \\
\hline Top Core 49X & 454.60 & 4.939 & 4.912 \\
\hline Top slump in Core $49 \mathrm{X}$ & 456.15 & 5.032 & 4.999 \\
\hline Base slump in Core $49 \mathrm{X}$ & 462.23 & 5.033 & 4.999 \\
\hline Top Core 50X & 464.20 & 5.142 & 5.457 \\
\hline Top slump in Core $50 \mathrm{X}$ & 470.23 & 5.479 & 5.794 \\
\hline Top Core 51X & 473.90 & 5.479 & 5.794 \\
\hline Base slump in Core $51 \mathrm{X}$ & 476.22 & 5.479 & 5.794 \\
\hline Top Core $52 \mathrm{X}$ & 483.60 & 5.860 & - \\
\hline Top slump in Core $52 \mathrm{X}$ & 484.50 & 5.906 & - \\
\hline Top Core 53X & 493.30 & 5.906 & - \\
\hline Base slump in Core $53 \mathrm{X}$ & 495.70 & 5.906 & - \\
\hline Top Core $54 \mathrm{X}$ & 502.90 & 6.275 & - \\
\hline Top Core 55X & 512.60 & 6.780 & - \\
\hline Top slump in Core $55 \mathrm{X}$ & 516.75 & 6.995 & - \\
\hline Base slump in Core $55 \mathrm{X}$ & 520.20 & 6.995 & - \\
\hline Top Core 56X & 522.20 & 7.098 & - \\
\hline Top slump in Core $56 \mathrm{X}$ & 525.20 & 7.253 & - \\
\hline Base slump in Core $56 \mathrm{X}$ & 530.40 & 7.253 & - \\
\hline Base Core 56X & 532.02 & 7.337 & - \\
\hline \multicolumn{4}{|l|}{ 154-929A- } \\
\hline Top Core $35 \mathrm{X}$ & 320.20 & -0.012 & -0.012 \\
\hline Top turbidite in Core $35 \mathrm{X}$ & 324.35 & 0.076 & 0.076 \\
\hline Base turbidite in Core $35 \mathrm{X}$ & 324.42 & 0.076 & 0.076 \\
\hline Top Core 36X & 330.00 & 0.420 & 0.400 \\
\hline Top Core $37 \mathrm{X}$ & 339.70 & 1.010 & 1.071 \\
\hline Top slump in Core $37 \mathrm{X}$ & 348.10 & 1.417 & 1.478 \\
\hline Base slump in Core $37 \mathrm{X}$ & 348.30 & 1.417 & 1.478 \\
\hline Top Core $38 \mathrm{X}$ & 349.40 & 1.475 & 1.579 \\
\hline Top turbidite in Core $38 \mathrm{X}$ & 355.75 & 1.783 & 1.874 \\
\hline Base turbidite in Core $38 \mathrm{X}$ & 355.83 & 1.783 & 1.874 \\
\hline Top Core $39 \mathrm{X}$ & 359.00 & 1.936 & 2.039 \\
\hline Top Core 40X & 368.50 & 2.442 & 2.504 \\
\hline Top Core $41 \mathrm{X}$ & 378.10 & 2.952 & 2.966 \\
\hline Top turbidite in Core $41 \mathrm{X}$ & 383.55 & 3.176 & 3.190 \\
\hline Base turbidite in Core $41 \mathrm{X}$ & 383.64 & 3.176 & 3.190 \\
\hline Top Core $42 X$ & 387.70 & 3.342 & 3.356 \\
\hline Top Core $43 \mathrm{X}$ & 397.40 & 3.740 & 3.700 \\
\hline Top Core $44 \mathrm{X}$ & 407.10 & 4.221 & - \\
\hline Top? slump in Core $44 \mathrm{X}$ & 409.70 & 4.329 & - \\
\hline Base? slump in Core $44 \mathrm{X}$ & 414.20 & 4.329 & - \\
\hline Top Core $45 \mathrm{X}$ & 416.70 & 4.443 & - \\
\hline Top turbidite/slump in Core $45 \mathrm{X}$ & 420.55 & 4.603 & - \\
\hline Top Core $46 \mathrm{X}$ & 426.40 & 4.603 & - \\
\hline Base turbidite/slump in Core $46 \mathrm{X}$ & 427.70 & 4.603 & - \\
\hline Top Core $47 \mathrm{X}$ & 436.10 & 4.952 & - \\
\hline Top Core $48 \mathrm{X}$ & 445.70 & 5.442 & - \\
\hline Top Core $49 \mathrm{X}$ & 455.30 & 5.918 & - \\
\hline Top Core 50X & 465.00 & 6.367 & - \\
\hline Top turbidite in Core 50X & 471.23 & 6.648 & - \\
\hline Base turbidite in Core 50X & 471.28 & 6.648 & - \\
\hline Top turbidite in Core $50 \mathrm{X}$ & 472.67 & 6.711 & - \\
\hline Base turbidite in Core 50X & 472.99 & 6.711 & - \\
\hline Top Core 51X & 474.60 & 6.794 & - \\
\hline Top turbidite in Core $51 \mathrm{X}$ & 481.90 & 7.159 & - \\
\hline Base turbidite in Core 51X & 482.18 & 7.159 & - \\
\hline Top Core $52 X$ & 484.00 & 7.271 & - \\
\hline Top turbidite in Core $52 \mathrm{X}$ & 492.25 & 7.674 & - \\
\hline Base turbidite in Core $52 \mathrm{X}$ & 492.50 & 7.674 & - \\
\hline Top turbidite in Core $52 \mathrm{X}$ & 492.60 & 7.679 & - \\
\hline Base turbidite in Core $52 \mathrm{X}$ & 493.07 & 7.679 & - \\
\hline Top Core 53X & 493.50 & 7.700 & - \\
\hline Top turbidite in Core $53 \mathrm{X}$ & 494.57 & 7.754 & - \\
\hline Base turbidite in Core 53X & 494.74 & 7.754 & - \\
\hline Top Core 54X & 503.20 & 8.177 & - \\
\hline Top Core $55 \mathrm{X}$ & 507.80 & 8.487 & - \\
\hline
\end{tabular}

Notes: The cumulative age has been measured below the lowest sample in which $S$. delphi is absent in each hole. Composite ages relate to correlations between holes (see Table 4) and the location of horizons relative to the topmost occurrence of $S$. delphix in Hole 929A. For both time scales, the time intervals between horizons within each core are determined from the sedimentation rates cited in Table 1. Redeposited intervals have been treated as though they accumulated instantaneously. $-=$ value could not be calculated. 
Table 3. Cumulative and composite ages for planktonic foraminifer and nannofossil biostratigraphic events.

\begin{tabular}{|c|c|c|c|c|c|c|c|c|c|c|c|c|}
\hline \multirow[b]{2}{*}{ Event } & \multicolumn{3}{|c|}{ Hole 925A } & \multicolumn{3}{|c|}{ Hole 926B } & \multicolumn{3}{|c|}{ Hole 928B } & \multicolumn{3}{|c|}{ Hole 929A } \\
\hline & $\begin{array}{l}\text { Depth } \\
\text { (mbsf) }\end{array}$ & $\begin{array}{l}\text { Cumulative } \\
\text { age (Ma) }\end{array}$ & $\begin{array}{c}\text { Composite } \\
\text { age (Ma) }\end{array}$ & $\begin{array}{l}\text { Depth } \\
\text { (mbsf) }\end{array}$ & $\begin{array}{l}\text { Cumulative } \\
\text { age (Ma) }\end{array}$ & $\begin{array}{l}\text { Composite } \\
\text { age (Ma) }\end{array}$ & $\begin{array}{l}\text { Depth } \\
\text { (mbsf) }\end{array}$ & $\begin{array}{c}\text { Cumulative } \\
\text { age (Ma) }\end{array}$ & $\begin{array}{l}\text { Composite } \\
\text { age (Ma) }\end{array}$ & $\begin{array}{l}\text { Depth } \\
\text { (mbsf) }\end{array}$ & $\begin{array}{l}\text { Cumulative } \\
\text { age (Ma) }\end{array}$ & $\begin{array}{c}\text { Composite } \\
\text { age (Ma) }\end{array}$ \\
\hline \multicolumn{13}{|l|}{ Planktonic foraminifers } \\
\hline P. kugleri, Base Biozone N4 & $\begin{array}{r}500.59 \\
501.98\end{array}$ & $\begin{array}{r}-0.013 \\
0.043\end{array}$ & - & $\begin{array}{l}465.08 \\
466.60\end{array}$ & $\begin{array}{l}-0.177 \\
-0.118\end{array}$ & $\begin{array}{l}-0.115 \\
-0.081\end{array}$ & $\begin{array}{l}346.40 \\
347.36\end{array}$ & $\begin{array}{l}0.080 \\
0.122\end{array}$ & $\begin{array}{l}0.051 \\
0.093\end{array}$ & $\begin{array}{l}322.60 \\
324.10\end{array}$ & $\begin{array}{r}-0.030 \\
0.061\end{array}$ & $\begin{array}{r}-0.030 \\
0.061\end{array}$ \\
\hline \multirow{2}{*}{ Top P. opima, Base Biozone P22 } & 574.56 & 2.619 & - & 527.41 & 2.403 & 2.373 & 411.56 & 2.963 & 2.931 & 373.70 & 2.718 & 2.781 \\
\hline & 584.26 & 2.931 & 3.669 & 529.61 & 2.502 & 2.509 & 414.60 & 3.091 & 3.060 & 383.30 & 3.165 & 3.180 \\
\hline \multirow{2}{*}{ Top C. cubensis, Base SZ P21b } & 593.10 & 3.305 & 4.054 & 572.81 & 4.102 & 4.039 & 433.24 & 3.897 & 3.895 & 399.6 & 3.849 & 3.809 \\
\hline & 593.82 & 3.335 & 4.084 & 574.31 & 4.161 & 4.098 & 434.91 & 3.977 & 3.975 & 401.07 & 3.922 & 3.882 \\
\hline \multirow[t]{2}{*}{ Base G. angulisuturalis, Base SZ P21a } & 646.65 & 5.477 & 6.244 & & & & 470.35 & 5.479 & 5.794 & 402.57 & 3.996 & - \\
\hline & 649.61 & 5.574 & 6.342 & & & & 474.60 & 5.479 & 5.794 & 409.21 & 4.308 & - \\
\hline \multirow[t]{2}{*}{ Top T. ampliapertura, Base Biozone P20 } & 649.61 & 5.574 & 6.342 & & & & 480.70 & 5.708 & 6.023 & 439.60 & 5.125 & - \\
\hline & 654.80 & 5.770 & 6.538 & & & & 482.10 & 5.780 & 6.095 & 441.30 & 5.209 & \\
\hline \multirow{2}{*}{ Top P. naguewichensis, Base Biozone P19 } & 725.00 & 8.467 & 9.235 & & & & & & & & & \\
\hline & 731.60 & 8.762 & 9.530 & & & & & & & & & \\
\hline \multirow[t]{2}{*}{ Top H. alabamensis } & 776.46 & 10.792 & 11.560 & & & & & & & & & \\
\hline & 777.03 & 10.852 & 11.620 & & & & & & & & & \\
\hline \multirow{2}{*}{ Top T. cerroazulensis, Base Biozone P18 } & 777.03 & 10.852 & 11.620 & & & & & & & & & \\
\hline & 777.42 & 10.894 & 11.661 & & & & & & & & & \\
\hline \multirow{2}{*}{ Top C. inflata, Base Biozone P17 } & 779.49 & 10.945 & 11.713 & & & & & & & & & \\
\hline & 779.49 & 11.111 & 11.879 & & & & & & & & & \\
\hline \multicolumn{13}{|l|}{ Nannofossils } \\
\hline \multirow[t]{2}{*}{ Top S. delphix } & 500.91 & 0.000 & - & 469.70 & 0.000 & 0.038 & 344.57 & 0.000 & -0.029 & 323.10 & 0.000 & 0.000 \\
\hline & 502.45 & 0.062 & - & 470.00 & 0.012 & 0.049 & 345.39 & 0.036 & 0.007 & 323.80 & 0.043 & 0.043 \\
\hline \multirow[t]{2}{*}{ Top S. ciperoensis, Base Biozone CN1 } & 502.85 & 0.078 & - & 495.42 & 1.059 & 1.080 & 371.60 & 1.279 & 1.158 & 341.60 & 1.102 & 1.163 \\
\hline & 507.50 & 0.265 & & 499.43 & 1.227 & 1.249 & 372.40 & 1.318 & 1.197 & 343.10 & 1.174 & 1.236 \\
\hline \multirow{2}{*}{ Top S. distentus, Base SZ CP19b } & 574.17 & 2.607 & 3.434 & 566.15 & 3.848 & 3.777 & 425.99 & 3.574 & 3.558 & 388.28 & 3.366 & 3.380 \\
\hline & 574.25 & 2.610 & 3.436 & 575.44 & 4.205 & 4.142 & 426.44 & 3.592 & 3.576 & 405.31 & 4.132 & 4.092 \\
\hline \multirow[t]{2}{*}{ Base S. ciperoensis, Base SZ CP19a } & 592.20 & 3.259 & 3.997 & & & & 431.74 & 3.825 & 3.809 & 405.31 & 4.132 & 4.092 \\
\hline & 593.33 & 3.315 & 4.064 & & & & 432.44 & 3.858 & 3.857 & 416.96 & 4.454 & - \\
\hline \multirow{2}{*}{ Base S. distentus, Base Biozone CP18 } & 654.60 & 5.763 & 6.530 & & & & 491.94 & 5.906 & - & 446.03 & 5.459 & - \\
\hline & 657.00 & 5.854 & 6.622 & & & & 496.85 & 5.965 & - & 455.06 & 5.906 & - \\
\hline \multirow{2}{*}{ Top R. umbilicus, Base Biozone CP17 } & 739.81 & 9.142 & 9.910 & & & & & & & 470.66 & 6.622 & - \\
\hline & 741.21 & 9.205 & 9.973 & & & & & & & 471.40 & 6.653 & - \\
\hline \multirow{2}{*}{ Top C. formosus, Base SZ CP16c } & 753.66 & 9.692 & 10.460 & & & & & & & 479.50 & 6.889 & - \\
\hline & 757.01 & 9.807 & 10.574 & & & & & & & 480.50 & 7.089 & - \\
\hline \multirow{2}{*}{ Top D. saipanensis, Base SZ CP16b } & 785.91 & 11.787 & 12.555 & & & & & & & 509.40 & 8.567 & - \\
\hline & 786.27 & 11.852 & 12.620 & & & & & & & 509.85 & 8.589 & - \\
\hline
\end{tabular}

Notes: For each event, the upper and lower limits of the position of the event is cited. SZ $=$ sub-biozone. $-=$ value could not be calculated. 


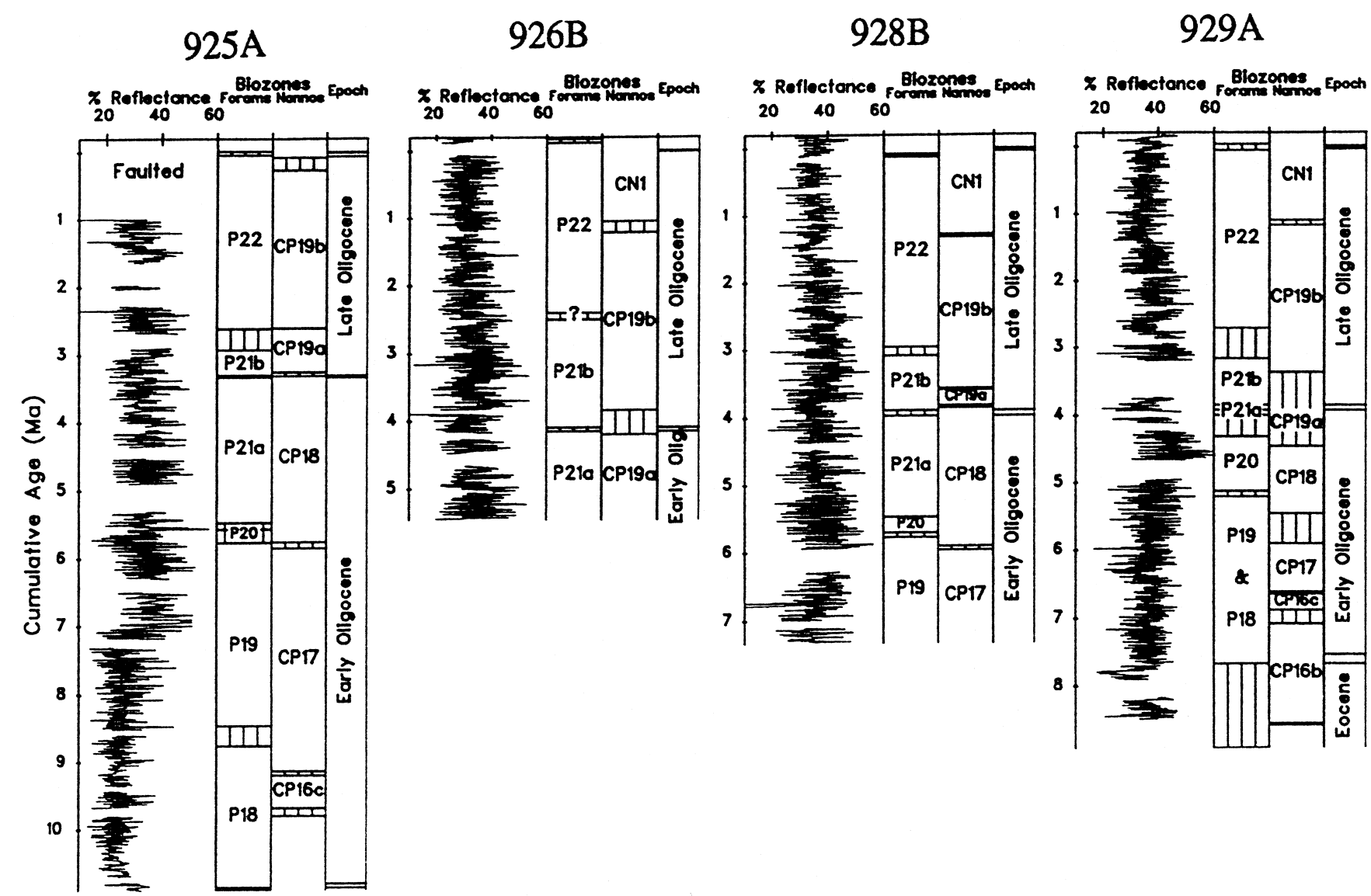

Figure 5. Reflectance data, excluding redeposited sediments, plotted on the cumulative time scale. For each site, the time interval represented by each cored interval was established from the sedimentation rates of the pelagic sediments derived from the spectral analyses and assuming $40 \mathrm{k} . \mathrm{y}$. per cycle (Fig. 4 ; Tables $1,2)$. The stratigraphic uncertainty in the location of biozone boundaries is indicated using vertical lines.

lower part of Hole 925A are plotted on the composite time scale in Figures 6 and 7.

\section{DISCUSSION AND CONCLUSIONS}

The interval durations of the planktonic foraminifer and nannofossil biozones for the various sites using the composite time scale are compared with the interval durations derived from the time scale of Berggren et al. (1995) in Figure 8. To allow the comparison, the datum used for the composite time scale (uppermost occurrence of $S$. delphix) has been fixed arbitarily at the base of Biozone N4, which is 23.8 Ma on the Berggren et al. (1995) time scale. The relative alignment used should not be thought to imply that any particular absolute age on the geochronology applies to particular levels of the composite time scale. As mentioned earlier, because it is accurately located on the Ceara Rise, the top of S. delphix has been used to denote the base of the Miocene. However, because this datum lies within a few meters of the lowest $P$. kugleri, there is only a minor disparity with the definition used by Berggren et al. (1995). A larger difference concerns the definition of the base of the nannofossil Biozone CN1 (uppermost $S$. ciperoensis here, uppermost $R$. bisecta for Berggren et al.).

There is a good measure of agreement between the sites on the Ceara Rise for the duration of the mid- to late Oligocene biozones where all four sites have been correlated in detail. However, a revision in the nannofossil biostratigraphy toward the base of Hole 926B may be warranted given the good correlation of reflectance data and planktonic foraminifer events with elsewhere, but the anomalously early start of nannofossil Sub-biozone CP19a. Figure 8 suggests that the Berggren et al. (1995) durations for Biozones P22 and P20 and Subbiozones P21b and CP19a are apparently longer, whereas their durations for Subbiozones P21a and CP19b are apparently shorter than inferred here. The durations implied by the composite time scale can be derived from Table 3. One of the largest proportionate differences in durations relates to Sub-biozone P21a and Biozone P20. As noted earlier, in reference to Figure 4, where the biostratigraphic events associated with these intervals were used to calculate net sedimentation rates at Sites 925 and 928, the results appeared to be exceptionally high.

For the earliest Oligocene, it appears that the previously published durations for Biozones P19, P18, and CP17 and Sub-biozone CP16b are shorter than those suggested here. However, only estimates from Site 925 are available because of the difficulty of correlation with the material exhibiting carbonate dissolution, slumping, and suspected faulting at Site 929 . This means that the composite time scale for this section is actually a cumulative time scale. The core recovery for the lowermost Oligocene was approximately $85 \%$ of penetrated thickness. Therefore, there are likely to be larger errors associated with the composite time scale for the early Oligocene than for the mid- to late Oligocene.

During Leg 154, the late Oligocene was recognized as occurring between the uppermost occurrence of $S$. delphix and the uppermost common occurrence of foraminifer Chiloguebelina cubensis. The latter datum level was found to be easy to recognize consistently because $C$. cubensis is fairly abundant up to the level of its last occurrence on the Ceara Rise. Elsewhere, rare individuals of this taxa can be found at higher levels. The composite time scale results in maxi- 
Table 4. Composite ages of the tie points used for correlation of reflectance series between sites.

\begin{tabular}{|c|c|c|c|c|c|c|c|c|}
\hline \multirow[b]{2}{*}{$\begin{array}{l}\text { Composite } \\
\text { age (Ma) }\end{array}$} & \multicolumn{2}{|c|}{ Hole 925A } & \multicolumn{2}{|c|}{ Hole 926B } & \multicolumn{2}{|c|}{ Hole 928B } & \multicolumn{2}{|c|}{ Hole 929A } \\
\hline & $\begin{array}{c}\text { Core } \\
\text { no. }\end{array}$ & $\begin{array}{l}\text { Depth } \\
\text { (mbsf) }\end{array}$ & $\begin{array}{c}\text { Core } \\
\text { no. }\end{array}$ & $\begin{array}{l}\text { Depth } \\
\text { (mbsf) }\end{array}$ & $\begin{array}{c}\text { Core } \\
\text { no. }\end{array}$ & $\begin{array}{l}\text { Depth } \\
\text { (mbsf) }\end{array}$ & $\begin{array}{c}\text { Core } \\
\text { no. }\end{array}$ & $\begin{array}{l}\text { Depth } \\
\text { (mbsf) }\end{array}$ \\
\hline-0.012 & & & $50 X$ & 468.40 & $37 X$ & 344.95 & $35 X$ & $322.90 *$ \\
\hline 0.316 & & & $51 X$ & 476.90 & $38 X$ & 353.45 & $35 X$ & $328.30 *$ \\
\hline 0.428 & & & $51 X$ & 479.80 & $38 \mathrm{X}$ & $355.80 *$ & $36 X$ & 330.45 \\
\hline 0.652 & & & $52 X$ & 485.30 & $39 X$ & 360.55 & $36 X$ & $334.15 *$ \\
\hline 0.940 & & & $53 X$ & 492.10 & $39 X$ & 366.60 & $36 \mathrm{X}$ & $338.90 *$ \\
\hline 1.121 & & & $53 X$ & $496.40^{*}$ & $40 X$ & 370.85 & & \\
\hline 1.364 & & & $54 X$ & 502.65 & $40 X$ & $375.85^{*}$ & $37 X$ & 345.75 \\
\hline 1.564 & & & $54 \mathrm{X}$ & $507.50 *$ & $41 X$ & 380.24 & & \\
\hline 1.773 & & & $55 \mathrm{X}$ & 512.75 & $41 X$ & $385.69 *$ & $38 \mathrm{X}$ & 353.65 \\
\hline 1.974 & & & $55 \mathrm{X}$ & 518.00 & $42 X$ & 390.40 & $38 \mathrm{X}$ & $357.90 *$ \\
\hline 2.049 & $26 \mathrm{R}$ & 531.95 & $56 \mathrm{X}$ & 519.85 & $42 X$ & $392.25 *$ & $39 \mathrm{X}$ & 359.20 \\
\hline 2.405 & $27 \mathrm{R}$ & 538.95 & $56 X$ & $528.15^{*}$ & $43 X$ & 399.85 & $39 \mathrm{X}$ & 366.15 \\
\hline 2.645 & & & $57 X$ & 532.80 & $43 X$ & $405.55^{*}$ & $40 X$ & 371.15 \\
\hline 2.842 & & & $58 \mathrm{X}$ & 538.85 & $44 X$ & 409.45 & $40 X$ & $374.85 *$ \\
\hline 3.108 & $30 \mathrm{R}$ & 566.05 & $58 \mathrm{X}$ & $546.50 *$ & & & $41 \mathrm{X}$ & 381.55 \\
\hline 3.252 & $30 \mathrm{R}$ & $570.65 *$ & $59 X$ & 551.40 & $45 X$ & 420.10 & & \\
\hline 3.436 & $31 \mathrm{R}$ & 574.25 & $59 \mathrm{X}$ & $556.70 *$ & & & & \\
\hline 3.508 & $31 \mathrm{R}$ & $576.55^{*}$ & $60 X$ & 558.40 & & & & \\
\hline 3.632 & & & $60 X$ & $561.95 *$ & $46 X$ & 427.79 & & \\
\hline 3.677 & $32 \mathrm{R}$ & 584.45 & $60 X$ & $563.25^{*}$ & $46 X$ & 428.54 & & \\
\hline 3.821 & $32 \mathrm{R}$ & $587.95 *$ & & & & & $43 X$ & 399.85 \\
\hline 3.858 & & & $61 X$ & 568.20 & $46 X$ & 432.49 & $43 X$ & $400.60 *$ \\
\hline 4.059 & & & & & $47 X$ & 436.95 & $43 X$ & $404.65 *$ \\
\hline 4.143 & $33 R$ & 595.25 & & & $47 X$ & $438.70 *$ & & \\
\hline 4.246 & $33 R$ & $597.75 *$ & $62 X$ & 578.20 & $47 X$ & 440.70 & & \\
\hline 4.542 & $34 \mathrm{R}$ & 604.05 & $63 \mathrm{X}$ & 590.20 & $48 \mathrm{X}$ & $446.60 *$ & & \\
\hline 5.056 & $35 \mathrm{R}$ & 615.75 & $64 X$ & 598.70 & $49 X$ & $463.25^{*}$ & & \\
\hline 5.340 & $36 \mathrm{R}$ & 622.95 & $64 \mathrm{X}$ & $605.80 *$ & & & & \\
\hline 5.558 & $36 \mathrm{R}$ & $628.25^{*}$ & & & $50 X$ & 466.00 & & \\
\hline 6.085 & $38 \mathrm{R}$ & 641.82 & & & $51 X$ & $481.90 *$ & & \\
\hline
\end{tabular}

Notes: The datum 0.0 Ma is the topmost occurrence of S. delphix in Hole 929A. Age intervals were determined from cumulative ages of pairs of tie points within the same core (i.e., based on the sedimentation rates cited in Table 1$){ }^{*}=$ position used to estimate age intervals between tie points.

mum estimates for the duration of the late Oligocene for Sites 926 , 928 , and 929 of $4.06,4.00$, and 3.88 m.y., respectively (Table 3 ). This range of ages provides an indication of the uncertainty in the procedures used here (e.g., the assumption of constant sedimentation rates within core pairs, incorrect correlations, and biostratigraphic uncertainty). For comparison, the late Oligocene lasted from 28.5 to 23.8 Ma or an interval of 4.7 m.y. based on the same biostratigraphic events and ages derived from the time scale of Berggren et al. (1995). This represents a considerable disparity. The top common occurrence of $C$. cubensis corresponds to the base of Sub-biozone P21b, which is associated with the problematic net sedimentation rates at Sites 928 and 925. If this event occurred about 0.7 m.y. later than the Berggren et al. (1995) time scale implies, Sub-biozone P21b would be shorter and Sub-biozone P21a would be longer, which is in much closer agreement with the composite time scale. More work is required to analyze the global and regional abundance patterns of $C$. cubensis. It is possible that this species persisted at greater abundance in the western equatorial Altantic than elsewhere, leading to a highly diachronous datum level.

Another noticeable difference between the time scales is the temporal relationship between the planktonic foraminifer and nannofossil biozones. Berggren et al. (1995) related biostratigraphic events from the two schemes to time by means of magnetostratigraphy, whereas here they were related to time by means of the sedimentary cycles. As an example of the differences according to Berggren et al. (1995) the base of nannofossil Sub-biozone CP19a (base of S. ciperoensis) occurs below the base of foraminifer Sub-biozone P21a (lowest occurrence of $G$. angulisuturalis). However, on the Ceara Rise the base of Sub-biozone CP19a occurs around 2 m.y. later, very close to the base of Sub-biozone P21b (uppermost occurrence of $C$. cubensis) in at least three sites on the Ceara Rise.

Until further data are available, the disagreement between the time scales is difficult to interpret; it might be related to one or several factors. The possiblity that strata are missing from the mid- to late Oligocene part of the Ceara Rise sections appears unlikely given the correlations between sites in Figures 7 and 8. Only widespread condensation or exceptionally slow rates of sedimentation across the whole rise could account for missing cycles yet correlatable time series. However, only Site 929 is known to have undergone significant dissolution in the Oligocene, and intervals of thin sedimentary cycles are restricted to that site and the very lowest Oligocene at Site 925 (Fig. 4; Table 1). Another possibility is that there is an important difference in the ages of the biostratigraphic events observed on the Ceara Rise compared to elsewhere. This could result from miscalibration or diachroneity as demonstrated for Neogene planktonic microfossils (Spencer-Cervato et al., 1994). Berggren et al. (1995) preferred to infer undetected hiatuses as a significant factor for inter-site correlations, but it remains possible that diachronism is important at some levels.

Despite the lack of magnetostatigraphic data in Leg 154 sediments, it should prove possible to transfer these time estimates to other places possessing palaeomagnetic control by using strontium isotope data, which can provide precision in correlation of less than 0.3 m.y. in the Oligocene (Mead and Hodell, 1995). At present, the Oligocene time scale is based on interpolation of the ages of seafloor magnetic anomalies over a very long interval using assumptions that can give rise to significant errors (Wilson, 1993). If the Ceara Rise cyclostratigraphy can be related to the geomagnetic record, then the refinement of the mid- to late Oligocene geologic time scale could be comparable to the results for more recent times (e.g., Shackleton et al., 1995).

\section{ACKNOWLEDGMENTS}

GPW, NJS, and PNP were supported during this work by Grant No. GST/02/971 from NERC under ODP Special Topic funds.

\section{REFERENCES}

Berger, A., and Loutre, M.F., 1994. Astronomical forcing through geological time. In de Boer, P.L., and Smith, D.G. (Eds.), Orbital Forcing and Cyclic Sequences. Spec. Publ. Int. Assoc. Sedimentol., 19:15-24. 
Berggren, W.A., Kent, D.V., Swisher, C.C., III, and Aubry, M.-P., 1995. A revised Paleogene geochronology and chronostratigraphy. In Berggren, W.A., Kent, D.V., Aubry, M.P., and Hardenbol, J. (Eds.), Geochronology, Time Scales and Global Stratigraphic Correlation: Spec. Publ.-Soc. Econ. Paleontol. Mineral., 54:129-212.

Curry, W.B., Shackleton, N.J., Richter, C., et al., 1995. Proc. ODP, Init. Repts., 154: College Station, TX (Ocean Drilling Program).

Fischer, A.G., De Boer, P.L., and Premoli Silva, I., 1990. Cyclostratigraphy. In Ginsburg, R.N., and Beaudoin, B. (Eds.), Cretaceous Resources, Events and Rhythms: Dordrecht (Kluwer, Academic Press), 139-172.

Gale, A.S., 1989. A Milankovitch scale for Cenomanian time. Terra Nova, $1: 420-425$.

Hartl, P., Tauxe, L., and Herbert, T., 1995. Earliest Oligocene increase in South Atlantic productivity as interpreted from "rock magnetics" at Deep Sea Drilling Site 522. Paleoceanography, 10:311-326.

Hays, J.D., Imbrie, J., and Shackleton, N.J., 1976. Variations in the Earth's orbit: pacemaker of the ice ages. Science, 194:1121-1132.

Herbert, T.D., 1992. Paleomagnetic calibration of Milankovitch cyclicity in Lower Cretaceous sediments. Earth Planet. Sci. Lett., 112:15-28.

, 1994. Reading orbital signals distorted by sedimentation: models and examples. In de Boer, P.L., and Smith, D.G. (Eds.), Orbital Forcing and Cyclic Sequences. Spec. Publ. Int. Assoc. Sedimentol., 19: 483-507.

Hilgen, F.J., 1991. Astronomical calibration of Gauss to Matuyama sapropels in the Mediterranean and implication for the geomagnetic polarity time scale. Earth Planet. Sci. Lett., 104:226-244.

Hilgen, F.J., and Langereis, C.G., 1989. Periodicities of $\mathrm{CaCO}_{3}$ cycles in the Pliocene of Sicily: discrepancies with the quasi-periods of the Earth's orbital cycles? Terra Nova, 1:409-415.

House, M.R., 1995. Devonian precessional and other signatures for establishing a Givetian timescale. In House, M.R., and Gale, A.S., Orbital Forcing Timescales and Cyclostratigraphy. Geol. Soc. Spec. Publ. London, 85:37-49.

Imbrie, J., Hays, J.D., Martinson, D.G., McIntyre, A., Mix, A.C., Morley, J.J., Pisias, N.G., Prell, W.L., and Shackleton, N.J., 1984. The orbital theory of Pleistocene climate: support from a revised chronology of the marine $\delta^{18} \mathrm{O}$ record. In Berger, A., Imbrie, J., Hays, J., Kukla, G., and Saltzman, B. (Eds.), Milankovitch and Climate (Pt. 1), NATO ASI Ser. C, Math Phys. Sci., 126: Dordrecht (D. Reidel), 269-305.

Mead, G.A., and Hodell, D.A., 1995. Controls on the ${ }^{87} \mathrm{Sr} /{ }^{86} \mathrm{Sr}$ composition of seawater from the middle Eocene to Oligocene: Hole 689B, Maud Rise, Antarctica. Paleoceanography, 10:327-346.

Mead, G.A., Tauxe, L., and LaBrecque, J.L., 1986. Oligocene paleoceanography of the South Atlantic: paleoclimatic implications of sediment accumulation rates and magnetic susceptibility. Paleoceanography, 1:273284.
Press, W.H., Flannery, B.P., Teukolsky, S.A., and Vetterling, W.T., 1986. Numerical Recipes: The Art of Scientific Computing: Cambridge (Cambridge Univ. Press).

Priestley, M.B., 1981. Spectral Analysis and Time Series: London (Academic Press).

Sander, B., 1936. Beitrage zur Kenntis der Anlagerungsgefuge rhymischer Kalke und dolomite aus der trias. Min. Petrogr. Mitt., 48:27-209.

Schwarzacher, W., 1993. Cyclostratigraphy and the Milankovitch Theory: London (Elsevier).

Shackleton, N.J., Berger, A., and Peltier, W.A., 1990. An alternative astronomical calibration of the lower Pleistocene timescale based on ODP Site 677. Trans. R. Soc. Edinburgh: Earth Sci., 81:251-261.

Shackleton, N.J., Crowhurst, S., Hagelberg, T., Pisias, N.G., and Schneider, D.A., 1995. A new late Neogene time scale: application to Leg 138 sites. In Pisias, N.G., Mayer, L.A., Janecek, T.R., Palmer-Julson, A., and van Andel, T.H. (Eds.), Proc. ODP, Sci. Results, 138: College Station, TX (Ocean Drilling Program), 73-101.

Spencer-Cervato, C., Thierstein, H.R., Lazarus, D.B., and Beckmann, J.-P., 1994. How synchronous are Neogene marine plankton events? Paleoceanography, 9:739-763.

Sprenger, A., and Ten Kate, W.G., 1993. Orbital forcing of calcilutite-marl cycles in southeast Spain and an estimate for the duration of the Berriasian Stage. Geol. Soc. Am. Bull., 105:807-818.

Van Echelpoel, E., and Weedon, G.P., 1990. Milankovitch cyclicity and the Boom Clay Formation: an Oligocene siliciclastic shelf sequence in Belgium. Geol. Mag., 127:599-604.

Weedon, G.P., 1989. The detection and illustration of regular sedimentary cycles using Walsh power spectra and filtering, with examples from the Lias of Switzerland. J. Geol. Soc. London, 146:133-144.

, 1993. The recognition and implications of orbital forcing of climate and sedimentary cycles. In Wright, V.P. (Ed.), Sedimentology Review: Oxford (Blackwell), 31-50.

Wilson, D.S., 1993. Confirmation of the astronomical calibration of the magnetic polarity timescale from seafloor spreading. Nature, 364:788-790.

Date of initial receipt: 11 December 1995

Date of acceptance: 29 April 1996

Ms 154SR-103 


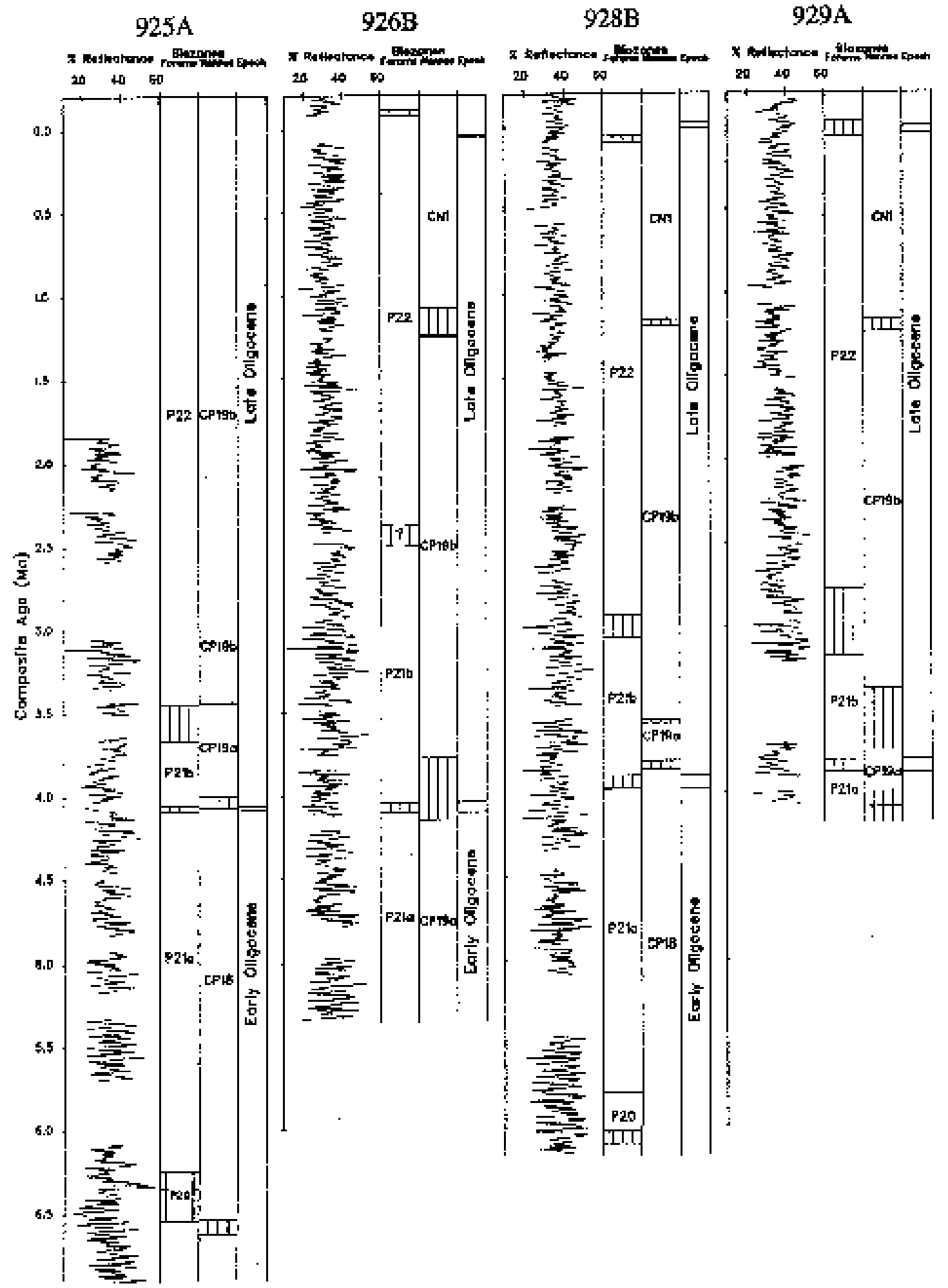

Figure 6. Reflectance data, excluding redeposited sediments, plotted on the composite time scale. For this time scale, individual core data sets were correlated visually between sites. In the early Oligocene, only data from Site $925 \mathrm{~A}$ are used, so that the composite time scale is equivalent to the cumulative time scale for that site. 


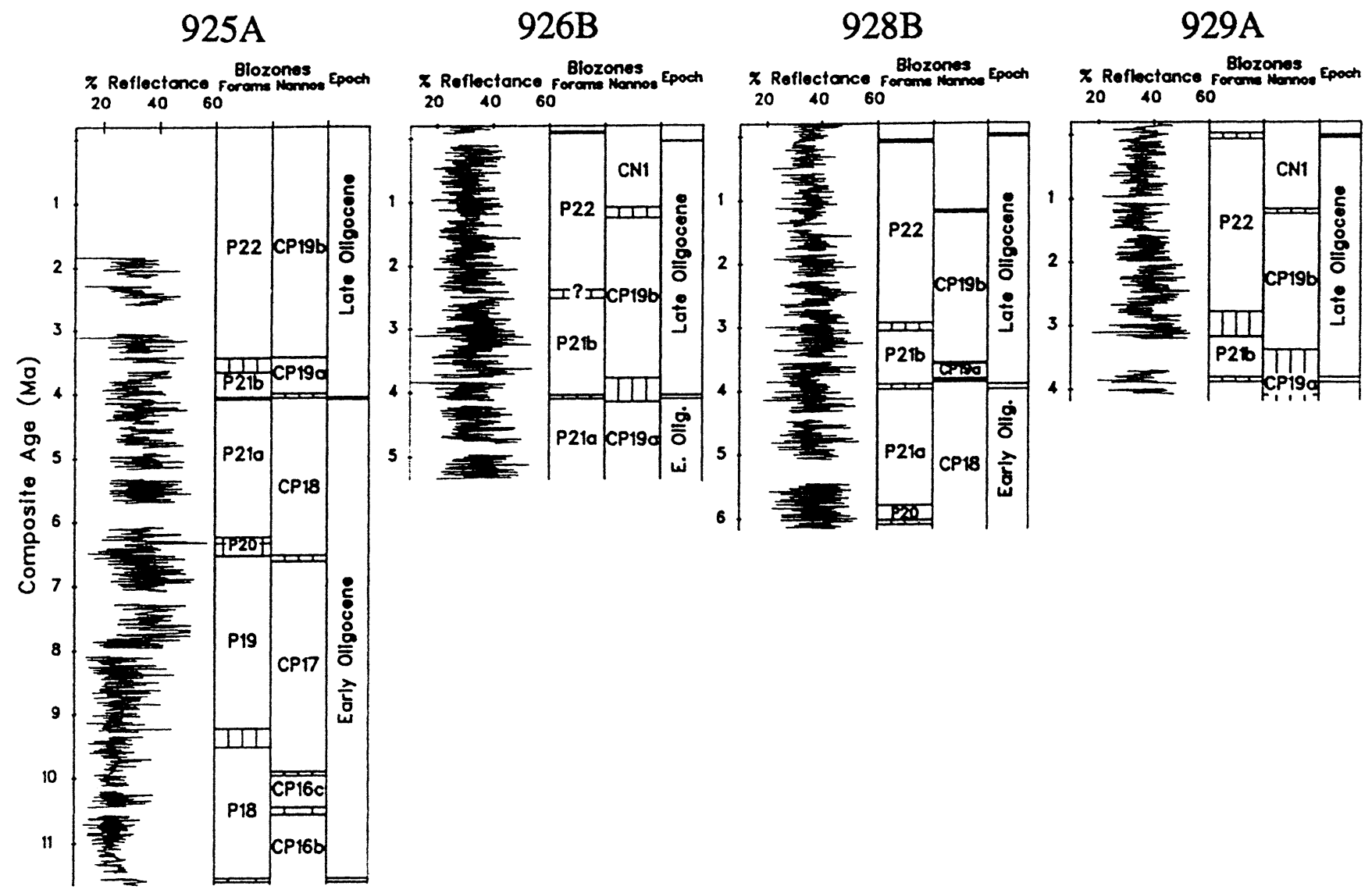

Figure 7. Reflectance data, plotted on the composite time scale. Note the improvement in consistency of ages for biozonal boundaries compared to the cumulative time scale (Fig. 5).

Figure 8. Comparison of biozone boundary ages and interval durations between the composite time scale and the geologic time scale of Berggren et al. (1995). The zero datum for the Ceara Rise composite time scale has been artibitarily placed at the base of Biozone N4, which is $23.8 \mathrm{Ma}$ on the chronometric time scale. Berggren et al. (1995) adopted a different biostratigraphic event for the base of Biozone $\mathrm{CN} 1$ to that used here (see text). The short dashed line indicates where the event adopted here would occur on their time scale.

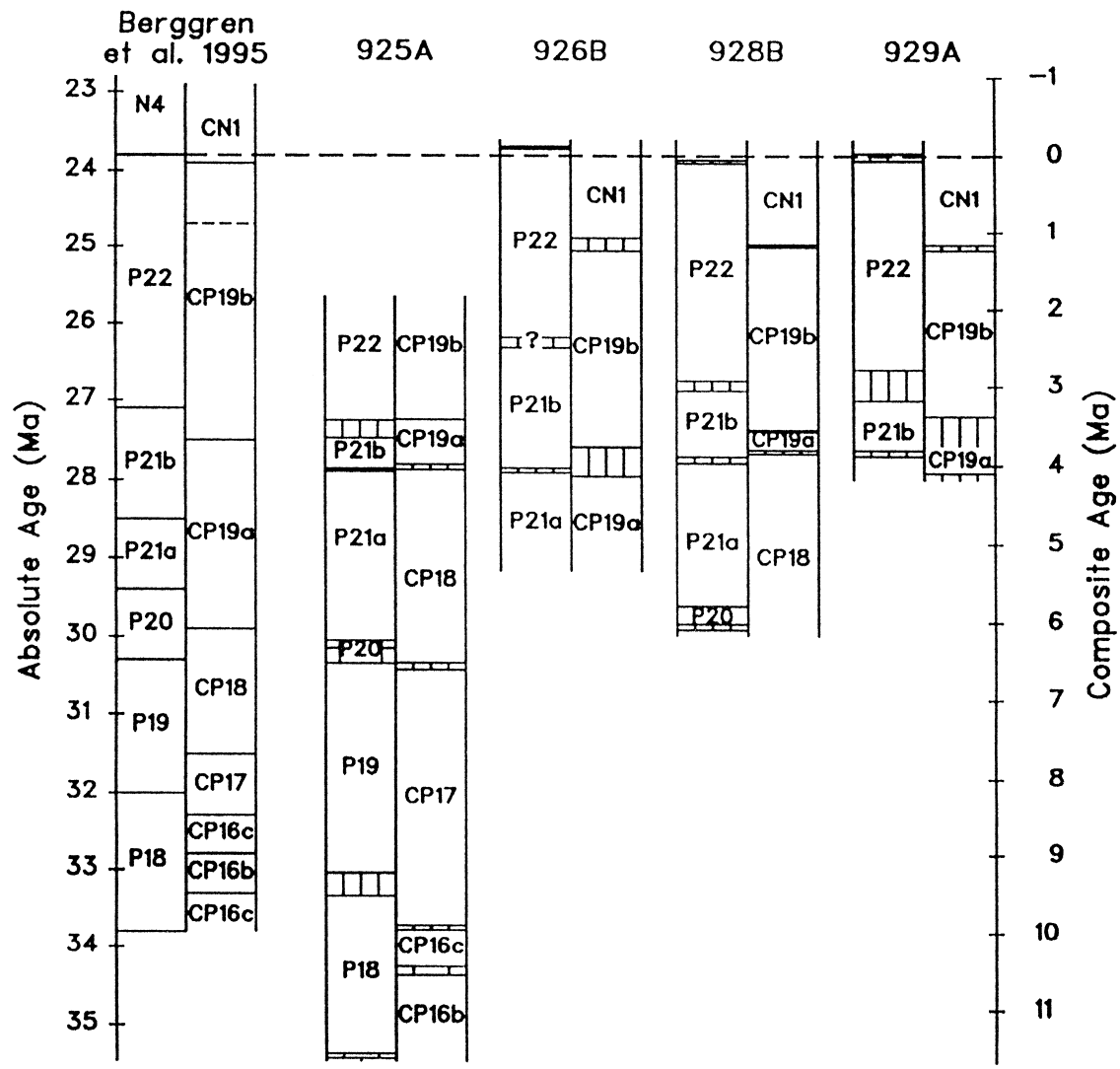

Table of Contents 